\title{
REVOlution in MANipulation LAW: THE NEW CFTC RULES AND THE URGENT NEED FOR ECONOMIC AND EMPIRICAL ANALYSES
}

\author{
Rosa M. Abrantes-Metz, ${ }^{*}$ Gabriel Rauterberg, ${ }^{\dagger}$ \& Andrew \\ Verstein
}

ABSTRACT

Three major banks have now admitted that their employees manipulated worldwide interest rates through the London Interbank Offered Rate (Libor), the most widely used interest rate index. Libor is the interest rate term for trillions of dollars of swaps and loans, and its manipulation may have been used to extract billions of dollars. These allegations come just as commodities manipulation law has been dramatically reformed and the Commodity Futures Trading Commission (CFTC) given vast new regulatory powers. This Article provides the first extended, scholarly analysis of the CFTC's new anti-manipulation rules. We consider the difficulty the rules address: Commodities manipulation claims have traditionally faced nearly insuperable obstacles to success in prosecuting manipulations like that of Libor. We then analyze the new rules, including their extension of the CFTC's powers to cover the swap market. The new rules appropriately lower the standards of pleading and proof, and yet the breadth of the new rules invites abuse. Both to implement the new rules and to prevent overuse, we argue for more elaborate, sophisticated, and creative economic analysis than ever before. We provide a wide-ranging overview of empirical tools for assessing manipulation claims, while re-engaging a decades-old debate on the place of empiricism in the laws of evidence and intent. We provide detailed

\footnotetext{
* Rosa M. Abrantes-Metz is a Principal in the Antitrust, Securities and Financial Regulation practices of Global Economics Group and an Adjunct Associate Professor at NYU's Stern School of Business. The author thanks David S. Evans and Albert Metz for discussions on the topic, and D. Daniel Sokol for suggestions. The views expressed are held by the authors and should not be attributed to the institutions they are affiliated with or their clients. † Attorney in private practice.

‡ Associate Research Scholar in Law, Lecturer in Law, and John R. Raben/Sullivan \& Cromwell Executive Director, Center for the Study of Corporate Law, Yale Law School.
} 
examples of how manipulation screens are necessary to complete the Dodd-Frank Wall Street Reform and Consumer Protection Act's (DoddFrank)'s revolution in manipulation law.

INTRODUCTION .359

I.MANIPULATION BEFORE DODD-FRANK: INSUPERABLE... .362

A. Definitions of Manipulation ……….........................................362

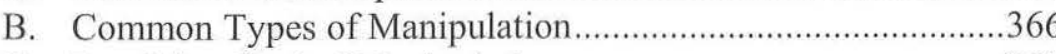

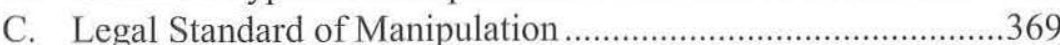

1. Price Artificiality and Causation............................................ 370

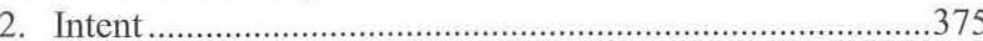

D. Manipulation is Hard to Prove ...................................................378

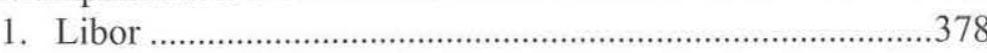

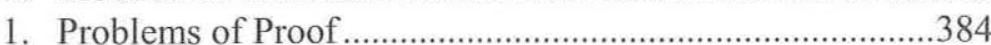

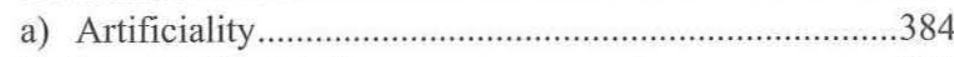

b) Intent is Hard to Prove ……........................................385

3. Problems of Scope ............................................................. 388

II.MANIPULATION AFTER DODD-FRANK: UNFINISHED ..............................391

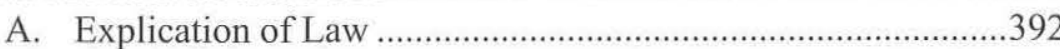

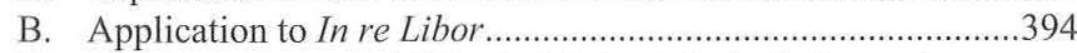

C. The Dangers of Dodd-Frank: Market Manipulation and

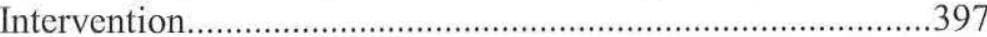

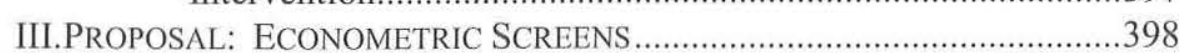

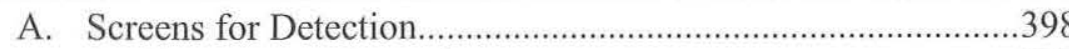

1. Government Detection..............................................399

2. Non-Government Detection.............................................402

B. Screens in Proof

1. Possible Empirical Analyses for a Hypothetical Case Brought Under Rule 180.1

2. Possible Empirical Analyses for a Hypothetical Case Brought Under Rule 180.2 ..............................................410

C. Screens at the Pleading Stage ..................................................414

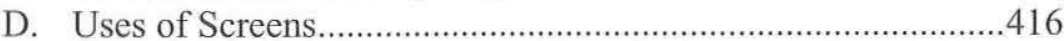

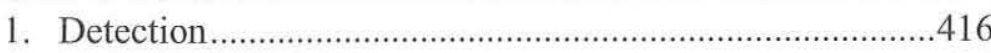

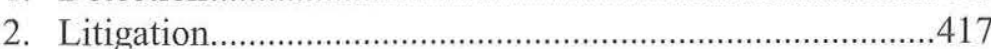

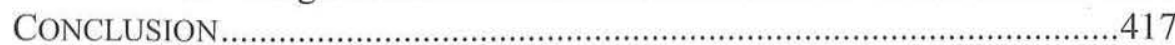

\section{INTRODUCTION}

Commodities manipulation claims have always been a mug's game.' Lacking so much as a definition within any statute, rule, or case, the concept of commodities manipulation is profoundly confused. Amidst the law's confusion, advice from scholars varies. There is no scholarly consensus as to the existence of manipulation, let alone the appropriate definition and avenue for prevention.

What emerges from the confusion is an almost unwinnable set of burdens. Plaintiffs must establish a manipulative intent that is conceptually and doctrinally among the most demanding mental state requirements anywhere in financial law. Moreover, the evidence for such intent is typically only highly ambiguous public behavior. Plaintiffs must also establish that the defendant's conduct causally resulted in an "artificial price," the definition of which is again confused and burdensome. Worst of all, courts have often been hostile to the use of statistical and economic arguments in buttressing and evaluating manipulation claims.

Unsurprisingly, the CFTC has won only one case in thirty-seven years. $^{2}$ Private plaintiffs are likely to prefer to plead Sherman Act section 2 , which does not require a showing of intent, and which has long been amenable to economic analysis. Even the Sherman Act's challenging market power element is just one part of manipulation's price artificiality element.

Yet, all at once, dramatic manipulation reform has arrived. The law governing market manipulation has been significantly altered: language tracking securities fraud prohibitions has been added, an attempt prong incorporated, and the scope of manipulation extended to include reckless manipulative conduct.

Also, under Dodd-Frank, the CFTC is instructed to regulate swaps, which are no longer exempt from the Commodity Exchange Act (CEA).

1. See, e.g., Robert C. Lower, Disruptions of the Futures Market: A Comment on Dealing with Market Manipulation, 8 YALE J. ON REG. 391, 391 (1991) (observing that "the seventy-year effort by the federal government to eliminate ... market manipulations has been more or less unsuccessful"); Jerry W. Markham, Manipulation of Commodity Futures Prices-The Unprosecutable Crime, 8 YALE J. ON Reg. 281 (1991).

2. See Andrew N. Kleit, Index Manipulation, the CFTC, and the Inanity of DiPlacido (Am. Enter. Inst. Reg-Markets Working Paper No. 09-06, 2009) (explaining that the CFTC charged NYMEX floor broker Anthony DiPlacido and traders with Avista Energy with

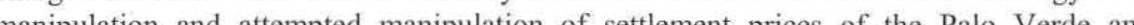
Caniforita California-Oregon Border electricity futures contracts traded on NYMEX from April through July of 1998). Note, however, that the CFTC has settled many claims.

3. Wall Street Reform and Consumer Protection Act (Dodd-Frank), Pub. L. No. 111 203, tit.VII (2010) 
Dodd-Frank explicitly creates anti-manipulation rules that apply to swaps and commodities alike. ${ }^{4}$ With a mandate and significantly expanded antimanipulation authority under Dodd-Frank, the CFTC has adopted potent new regulations to prosecute manipulation under the CEA. ${ }^{5}$ Although these new powers are broad and potentially dangerous, they are responding to increasing concern about the swap market.

Regulation of swaps is of profound importance. At least $\$ 500$ trillion dollars in notional value are at stake in the global swap market. This money has hitherto operated in a largely legally unaccountable space, uncleared and subject to opaque management; one need only remember the concerns at the time of the AIG, Lehman Brothers, and Bear Stearns failures to remember the systemic worries of swap failure. ${ }^{6}$

Abuses in the swap market underlie today's biggest financial story. Media, academics, consultants, regulators, and plaintiffs are increasingly focused on the $\$ 400$ trillion dollar interest rate swap market as allegations surface that Libor, the benchmark for most of the world's swaps, ${ }^{7}$ may have been manipulated, ${ }^{8}$ All over the world, major banks are admitting their employees' complicity in one of the greatest financial heists in history. Altering the interest rates paid by home mortgage borrowers and received by pension funds may have generated billions of dollars of illicit profits. If Congress was content to allow commodities manipulation before, it has

4. Id. $\S 753$.

5. Prohibition on the Employment, or Attempted Employment, of Manipulative and Deceptive Devices; Prohibition on Price Manipulation, 76 Fed. Reg. 41,398 (July 14, 2011).

6. See, e.g., Editorial, AIG and Systemic Risk, WALl St. J., Nov. 23, 2009, at A26 suggesting that "[f]or the last year, the entire Beltway theory of the financial panic has been based on the claim that the 'opaque,' unregulated CDS market had forced the Fed to take over AIG and pay off its counterparties, lest the system collapse").

7. LIBOR: The world's most important number, MONEYWEEK, Oct. 10, 2008, available at http://www moneyweek com/personal-finance/libor-the-worlds-most-importan t-numer-13816; BBA LIBOR: The world's most important number now tweets daily, BBA t-n (B) worlds-most-important-number-now-tweets-daily; Donald McKenzie, What's in a Number?, 30 LONDON REv. BoOKS 11 (2008) (noting that "Libor anchors contracts totaling about $\$ 300$ trillion, the equivalent of $\$ 45,000$ for every human being on the planet"); $c f$. Carrick Mollenkamp, Libor Fog: Bankers Cast Doubt on Key Rate Amid Crisis, Wall St. J., Apr. 16,2008 , at $\mathrm{Al}$ (reporting that $\$ 500$ trillion in contracts are indexed to Libor); INT'L Monetary Fund, Global Financial Stability Report: Financial Stress and Deleveraging Macrofinancial Implications and Policy xv (2008) (observing that "the "the LIBOR

8. See Carrick Mollenkamp \& Mark Whitehouse, Study Casts Doubt on Key Rate, Wall St. J., May 29, 2008, at Al.

9. Jean Eaglesham, Paul Vieira \& David Enrich, Traders Manipulated Key Rate, Bank Says, WALL ST. J., Feb. 17, 2012, at C1. signaled that commodities exchange prosecution is not to be dead letter. Swaps are simply too important and too relevant to slip through the cracks.

In response to these dramatic events and shifts in the legal landscape, this Article makes three principal contributions. It serves as the firs scholarship to examine and explain the new CEA anti-manipulation powers. In explicating these provisions, this Article explains the deficiencies the new provisions were meant to address, as well as the shortcomings and risks of the new manipulation rules. Second, it urges the increased use of statistical and economic tools in the evaluation of manipulation claims, arguing for their particular importance in this domain. Third, it provides examples of how courts have used such tools, and how they might best use them in the future.

The structure of the Article is as follows. In Part I, we explore and define manipulation. We then examine the law and theory of commodities manipulation as it existed prior to Dodd-Frank. In Part II, we explain the changes within and attendant to Dodd-Frank and provide a rationale for some of the most controversial parts of these reforms, including a lowered scienter requirement. In Part III, we then urge increased use of statistical and economic tools in the evaluation of manipulation claims, particularly at the pleading stage. These screens should be used offensively and defensively. Many manipulation schemes will be initially detected only by screens. Conversely, courts may wish to spare defendants the expense of discovery where there is scanty statistical evidence of manipulation. This will help limit the intimidating reach of the new rules. In the process, we give extensive examples of how these screens might work, based both on theory and on our professional experiences.

Arguments about the appropriate weight that should be given to empirical analyses in litigating intent belong to the genetic code of evidence law and scholarship. ${ }^{10}$ They can delve into the deep weeds of statistical detail, but they are ultimately disputes as to the epistemology of courts and agencies - arguments about how it is possible for a fact finder to know the facts upon which a judgment must ultimately rest. This Article

10. Lea Brilmayer, Second-Order Evidence and Bayesian Logic, 66 B.U. L. REv. 673 (1986); Lea Brilmayer \& Lewis Kornhauser, Review: Quantitative Methods and Legal Decisions, 46 U. CHI. L. Rev. 116 (1978); Michael O. Finkelstein \& William B. Fairley, A Bayesian Approach to Identification Evidence, 83 HARV. L. REV. 489 (1970); John Kaplan, Decision Theory and the Factfinding Process, 20 STAN. L. REV. 1065 (1968); Jonathan J. Koehler \& Daniel N. Shaviro, Veridical Verdicts: Increasing Verdict Accuracy Through the Use of Overtly Probabilistic Evidence and Methods, 75 CORNet L. REv. 247 (1990);

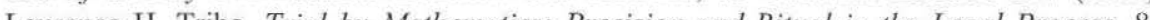
Laurence H. Tr. HARV. L. Rev. 1329 (1971); see also King Tise Co. v. Canichad, 526 U.S. 137 (1999); Daubert v. Merrell Dow Pharm., Inc., 509 U.S. 579 (1993); Frye v. United States, 293 F. 1013 (D.C. Cir. 1923) 
re-engages that debate from within manipulation law. It demonstrates both the law's current uses - often appropriate, and sometimes grudging - of empirical methods of establishing the four elements commonly associated with manipulation by providing an explication of the prominent uses of these methods in important litigation. Particularly with regard to intent, statistical and econometric methods are of greater importance to establishing or discrediting a plaintiff's case than many expect.

\section{MANipulation BEFore DodD-Frank: INSUPERABLE}

\section{A. Definitions of Manipulation}

The dysfunctional state of pre-Dodd Frank anti-manipulation law is perhaps best reflected in the statutory, doctrinal, and scholarly confusion concerning the concept of manipulation itself. Below we canvass this muddled territory. The CEA makes it a felony "to manipulate or attempt to manipulate the price of ... any commodity...."11 and creates a private right of action to accompany the government's civil and criminal enforcement capabilities. ${ }^{12}$ Yet no statute, regulation, or case defines manipulation for the purposes of the Commodity Exchange Act. ${ }^{13}$ According to Williams, "[t]he reason the Congress, the ABA, and the courts have not crafted an all-encompassing definition of "manipulation"' is because "[t]he concept is a constantly evolving one." 14 Others give a more pessimistic diagnosis: want of a definition has left the law "a murky miasma of questionable analysis and unclear effect."15

11. 7 U.S.C. $\$ 9(2012)$

12. Id. $\S 22(\mathrm{a}) ; i$ d. $\S 25(\mathrm{a})(1)$ ("Any person ... who violates this chapter or who willfully aids ... a violation of this chapter shall be liable for actual damages resulting from one or more of the transactions referred to in subparagraphs (A) through (D) of this paragraph and caused by such violation ....."). It was not always clear that there would be such a private right. See Philip McBride Johnson \& Thomas Lee Hazen, Commodities Regulation 1462 (2d. ed. 1989).

13. See In re Indiana Farm Bureau Coop. Ass'n, Inc., [1982-1984 Transfer Binder] Comm. Fut. L. Rep. (CCH) I 21,796, at 27,281 (CFTC Dec. 17, 1982) (explaining that "[n]either manipulation nor attempted manipulation is defined in the Commodity Exchange Act. That task has fallen to case-by-case judicial development"); $c f$. Prohibition on Price Manipulation, supra note 5, 76 Fed. Reg. at 41406-07 ("The Commission declines to adopt comments proposing a new economics-based definition of manipulation. Instead, as stated above, all relevant facts and circumstances must be considered in determining whether 2 d 350 (7th Cir.) eclining to define manipulation), cert. denied, 290

14. Jeffrey C. Williams, Manipulation on Trial: Economic analysis and the Hunt SILvER CASE xviii (1995)

15. 2 Timothy J. Snider, Regulation of the Commodities Futures and Options MARKETS 12.01, at $12-5$ (2d ed. 1995); see also Edward T. McDermott, Defining
With no determinative account, administrative and judicial opinions offer a grab bag of accounts of manipulation. In In re Henner, the hearing officer's opinion stated that:

"Manipulation" is a vague term used in a wide and inclusive manner, possessing varying shades of meaning, and almost always conveying the idea of blame-worthiness deserving of censure. There is usually also an implication of artificiality and of skillful and ingenious management. In its most common use it has reference to a speculator, or to a group of speculators who buy or sell produce, in such a way as to give outsiders the impression that such buying or selling is the result of natural forces. Hence the term includes excessive speculation, the spreading of false rumors, the working of syndicates to increase or depress prices, "wash sales," "matched orders," and "corners."

All of these notions - blameworthiness, artificiality, speculation, false impressions and rumors, collusion to affect price, and specific practicesare associated with manipulation, and each has held prominence in legal theory and in the law at some point.

Scholars and observers have been encouraged to offer definitions, and resulting interpretations of the state of the law, but the only ground of agreement has proved to be the difficulty of proving manipulation. As one scholar has put it, "Manipulation is difficult to define .... [D] [rawing a line between healthy economic behavior and that which is offensive has proved to be too subjective and imprecise to produce an effective regulatory tool."17

A recurrent theme is the identification of manipulation with distorted or unnatural prices. ${ }^{18}$ The former president of the New York Cotton Exchange at Congressional hearings on cotton price fluctuations defined manipulation as:

Manipulation in Commodity Futures Trading: The Futures "Squeeze," 74 Nw. U. L. REv. 202, 205 (1979) (calling manipulation law "an embarrassment-confusing, contradictory, complex, and unsophisticated").

16. 30 Agric. Dec. 1151 (U.S.D.A. 1971)

17. Lower, supra note 1, at 392; Craig Pirrong, Squeezes, Corpses, and the AntiManipulation Provisions of the Commodity Exchange Act, 17 REGULATION, no. 4, 1994 at 54 ("[T] define just wht of con ink, because the term 'manipulation' is used very imprecisely and indiscriminately.").

18. For artificiality in antitrust, see United States v. Socony-Vacuum Oil Co., 310 U.S. 150, 223 (1940) ("[M]anipulation in its various manifestations is implicitly an artificial stimulus applied to (or at times a brake on) market prices, a force which distorts those prices, a factor which prevents the determination of those prices by free competition alone."). 
$[A]$ ny and every operation or transaction or practice, the purpose of which is not primarily to facilitate the movement of the commodity at prices freely responsive to the forces of supply and demand; but, on the contrary, is capty and distortion of any kind in any market eithe relation to other markets. 19 any market either in itself or in its Likewise, Matthijs Nelemans has examined the connection between the
action and price pressure. ${ }^{20}$ prices:

Easterbrook is critical of efforts to find manipulation in artificial

An effort to isolate which "forces of supply and demand" are do failure. What is a "basic" People demand think of supply and demand as givens. People demand what they demand, and never mind the reasons artificial. ${ }^{21}$ There is no way to say what demand is real and what is

ainst objectiv

accounts, ${ }^{22}$ he proposes a subjective account that Yecesitful intent, a position several scholars share. ${ }^{23}$

Yet, there are problems with deceit-based accounts as well. It seems that some manipulation comes not from deceit, but from some exercise of market power. Pirrong and Russo both note that some manipulation concerns "the elimination of effective price competition in a market for cash commodities and/or futures contracts through the domination of supply or demand, and the exercise of that domination to intentionally

19. Markham, supra note 1, at 312; see also Cotton Prices: $H_{\text {end }}$ Subcomm. of the S. Comm. on Agriculture and Foreston Prices: Hearing Before a (asserting that Marsh's statement provides little guidance in definin Cong. 201-03 (1928) Collins Perdue, Manipulation of Futures Markets. Redefining defining manipulation); Wendy Rev. 345, 360 (1987) (explaining that it is difficult foning the Offense, 56 FORDHAM L. legislative history regarding the a "particularly unreliable refle meaning of manipulation, and that Marsh's statement offers 20. See Matthijs Neleflection of congressional understanding").

L. REv. 1169 (2008) (describing, Redefining Trade-Based Market Manipulation, 42 VAL. U.

21. Frank H. (describing how manipulation is creating superfluous "price pressure"). Markets, 59 J. Bus. S103, S117 (1986).

22. It should surprise no reader to find accounts that emphasize both artificiality and Lessons from Sumitomo 3 (Lee Christopher L. Gilbert, Manipulation of Metals Futures: 1537, 1997) (describing 3 (London Ctr. for Econ. Pol'y Research, Discussion Paper No. 23. See Charles R Kor manipulation can be best deterred).

Manipulation Class Actions, 52 WM. \& Mary The Misuse of Market Efficiency in Market to define Class Actions, 52 WM. \& MARY L. REv. 1111, 1135 (2011) (calling an ater satisfying"). produce artificially high or low prices." ${ }^{24}$

Some scholars deemphasize intent, focusing on objective characteristics of manipulation. Van Smith argues for a presumption of manipulation where traders do not offset their contracts before delivery. ${ }^{2.5}$ Perdue offers conduct-oriented definition of manipulation "as conduct that would be uneconomical or irrational, absent an effect on the market price."26 Friedman follows Perdue by comparing the trader's act to his behavior without manipulative intent. He does so by comparing the behavior to "what the long [trader] would have done if he simply did not take the anticipated impact into account," and then, "what the long [trader] would have done had he put out of mind the additional pressure created by a system of punitive sanctions for default."27

Of course, the more basic question is whether there is such a thing as manipulation at all. Fischel and Ross believe "legal prohibitions are unnecessary" in the futures markets. ${ }^{28}$ They claim that no objective test can detect manipulation, and all subjective tests that find manipulation also find fraud. ${ }^{29}$ As a result, there is no manipulation beyond what the law of fraud can already address. They are skeptical as to the existence of whole categories of putative manipulation, asserting that they are likely to be selfdeterring. The need to make prices rise through trading, but only after the manipulator has acquired the commodity "creates an intractable dilemma for the potential manipulator." ${ }^{30}$ The trading behavior that drives up prices for others drives up prices for the manipulator too, who must also face transaction costs.

They further emphasize that manipulation requires deployment of huge amounts of capital, ${ }^{31}$ that large positions are already largely prohibited by law, ${ }^{32}$ and that exchanges have an incentive to prevent manipulation. ${ }^{33}$ With no gainful manipulation detectable that is not fraud, Fischel and Ross

24. 2 PhILIP MCBride Johnson, Commodities Regulation $§ 5.03$, at 238 (1982); Craig Pirrong, Energy Market Manipulation: Definition, Diagnosis, and Deterrence, 31 ENERGY L.J. 1, $6(2010)$

25. M. Van Smith, Preventing the Manipulation of Commodity Futures Markets: To Deliver or Not to Deliver?, 32 Hastings L.J. 1569, 1605-06 (1981).

26. Perdue, supra note 19 , at 348 . Perdue also draws parallels to the antitrust concept of predatory pricing. $I d$. at 394 .

27. Richard D. Freidman, Stalking the Squeeze: Understanding Commodities Market Manipulation, 89 Mich. L. ReV. 30, 59 (1990).

28. Daniel R. Fischel \& David J. Ross, Should the Law Prohibit "Manipulation" in Financial Markets?, 105 Harv. L. REv. 503, 548 (1991).

29. Id.

30. Id. at 513 .

31. Id. at 513 .

32. Id at 549 .

33. Id. 
urge an end to the definitional and regulatory enterprise.

Fischel and Ross's manipulation nihilism is not the end of the discussion: Steve Thel responded that far more can alter price than fraud and fictitious trades. ${ }^{34}$ For example, a broad category of contract-based trades, such as executive compensation agreements, may be triggered by changes in external prices. If the payoff from the contract is great enough, it can be rational for a contractor to bid up the price of the asset. ${ }^{35}$ This manipulation is plausible and does not seem to be fraud.

\section{B. Common Types of Manipulation}

If it is challenging to find scholarly consensus on the proper definition of manipulation, it must suffice to define manipulation ostensibly, by pointing out several examples that are broadly accepted as manipulation, if only because the CEA does the same. It specifically prohibits "bucket[ing]" an order, "wash sale[s]," and "accommodation trade[s]." An effort to compile an exhaustive list of different manipulative schemes is likely to be incomplete since "[t]he methods and techniques of manipulation are limited only by the ingenuity of man." 38 That said, three main categories of manipulation are broadly accepted: delivery impairment, false information, and market rigging.

Delivery impairment includes cases that exploit disruptions in the delivery mechanisms, often by dominating or interfering with the supply of a cash commodity. Such manipulations are possible in commodities markets because of the relationship between the "cash" or "spot" market and the futures market. The cash market represents a purchase or sale of the existing commodity, while the futures market represents a promise to buy or sell in the future. Most futures contracts are cash settled, meaning the commodity is never delivered - the contract owner agrees to accept the value of the commodity instead. However, the contract owner, or "the long," usually has the right to demand physical delivery of the commodity, forcing her counterparty to purchase the commodity on the cash market. When the cash market is in some way impaired, and so delivery is impracticable, "the short" will have few options but to accept unfavorable

34. Steve Thel, $\$ 850,000$ in Six Minutes-The Mechanics of Securities Manipulation, 79 CORNELL L. Rev. 219 (1994)

35. Id.

36. 7 U.S.C. $\$ 6 \mathrm{~B}(\mathrm{a})(2)(\mathrm{D})(\mathrm{i})(2012)$.

37. Id. \$ 6C(a)(2)(A).

8. Cargill, Inc. v. Hardin, 452 F.2d 1154, 1163 (8th Cir. 1971).

39. 2 thomas A. Russo, Regulation of the Commodities Future and Options MARKETS $\$ 12.11$, at 12-18 (1983). terms of delivery or settlement. To make a stylized example, a short in the oil futures market may promise to deliver ten barrels of oil in a year to the long for $\$ 100$ per barrel. That may seem like a fine deal if oil is currently trading for $\$ 90$ per barrel. The short expects to settle her contract either with cash or by buying oil at the market price and then delivering it in satisfaction of her contract. However, it may be that the long insists on delivery at precisely the time that there are only five barrels for sale within easy shipment of the point of delivery. The short is in a bind; to satisfy her contract, she must contemplate transporting oil from far away at great cost. With local delivery so impaired, she may be willing to pay the long an attractive premium to satisfy her contract and, in any event, to pay a king's ransom for the five barrels that are available for delivery.

Squeezes and corners are two well-known delivery impairment scenarios. A corner is a kind of manipulation in which someone, taking advantage of the anonymity of futures trading, establishes a large [long] futures position calling for delivery in a particular delivery month. Waiting until those who have the contractual obligation for delivery have little time remaining, the cornerer surprises them by appearing eager to stand for delivery. Meanwhile, having obtained much of the deliverable grade locally available, the manipulator leaves those committed to make delivery the unenviable choice of paying express charges for transportation or buying back the futures contracts at a premium. ${ }^{4}$

While in a corner, the trader has control of virtually all of the available supply of the commodity underlying the futures contracts held by the trader ${ }^{41}$ in a squeeze a trader acquires a large futures position when there is a shortage of the underlying commodity. ${ }^{42}$ A squeeze occurs in the futures market alone, whereas a corner also involves manipulation in the

40. Williams, supra note 14, at 6; see also Gilbert, supra note 22, at 3 (explaining that "[t]he terms corner and squeeze tend to be used synonymously, but it is nevertheless usefu to follow Kyle (1984) in distinguishing between them. The crux of Kyle's distinction is whe ky (1984) in dis whether hyc maniplator an artificial shortage (a corner), usually in conjunction with futures market positions; or whether he operates solely in the futures market but exploits the delivery mechanism to distort the price of a particular future away from fundamental values (a squeeze). Squeezes, he notes, are over once delivery is made, while corners tend to last longer").

41. Markham, supra note 1, at 283 .

42. Id. at $284 \mathrm{n} .8$ (" $[\mathrm{A}]$ squeeze may be intentionally created or it may result from a natural shortage that traders seek to exploit. The latter event is frequently referred to as 'congestion,"') (citing REPORT OF THE CHIEF OF THE COMMODITY EXCHANGE

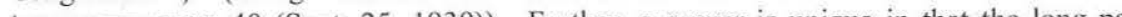
( must "bury the corps" (sell of the conmodity) afterwards without depressing prices and rendering the corner unprofitable. Markham, supra note 1, at 294 ("[An] FTC study found that congestion has price effects nearly as severe as a corner that is deliberately contrived to squeeze the shorts."). 
cash market. ${ }^{43}$ That is to say that a squeeze is possible where the manipulator has taken no long or short positions in the underlying commodity.

Delivery impairment strategies often require substantial amounts of capital and staying power, as well as tolerance for risk. If delivery proves easier than the manipulator guessed, then she may find herself receiving large supplies for which she has no use, and without enjoying a substantial price effect. For this reason, asymmetric information can be the manipulator's ally. A corner or squeeze is easier if the manipulator knows that delivery is likely to be impaired at some point. ${ }^{44}$

The second category of manipulative conduct, the spreading of false information, involves the indirect disruption of supply and demand by creation of a state of misinformation in the market place. Large amounts of buying or selling may sometimes send false signals to market participants that they too should buy or sell, but this is an expensive and unreliable technique. ${ }^{45}$ More common procedures are the dissemination of false information or impressions through rumors or price reports, or "wash sales"-transactions with one's self or affiliates with no economic substance. Such manipulation requires little to no capital and tends to be relatively short-lived, as the market self-corrects.

The last type of manipulation, which we may call market rigging, involves attempts by market professionals to tamper with the market by virtue of their position within the system of trade. For example, prices could be artificially high because brokers simply execute at an artificially high price to the disservice of their clients. This type of manipulation generally depends upon some or all of the following factors: lack of market liquidity (however short-term), conspiracy or at least tacit acceptance by a substantial number of market professionals, and some defect in the future's contract terms or some inefficiency in the cash market such that delivery of cash commodity is not practical. We may also include front-running, when a broker, having just received a large incoming transaction, trades on his own account in order to profit from the effects of a subsequent execution of the client order.

Many kinds of manipulation include elements from more than one of these general manipulative strategies. For example, a delivery impairment manipulation may be easier if one spreads false information about one's

43. Russo, supra note $39, \S 12-10$.

44. Markham notes that Hedgers and Speculators are equally likely to engage in manipulative trades as shown by the Ferruzzi soybean crisis. Markham, supra note 1, at 372; see also Craig Pirrong, Detecting Manipulation in Futures Markets: The Ferruzz Soybean Episode, 6 AM. L. \& ECON. Rev. 28 (2004).

45. See Fischel \& Ross, supra note 28 , at 512 . own position. Secrecy is important, as people know that it is dangerous to promise to deliver wheat to someone who already owns most of the deliverable wheat. If a trader did enter the contract by accident and found out about supply conditions, she could bring new supplies to the market (say, making arrangements for new wheat to be grown and delivered) to reduce the premium she must pay to cancel her obligations. The manipulator will profit most if he can keep the trader from realizing her predicament. ${ }^{46}$

Another mixed strategy may be found in a short-squeeze, which aims to depress prices to artificially low levels. In this instance, the manipulator becomes the short in a number of future contracts and then places into delivery a very large amount of the cash commodity. Not only does the dump of cash commodity onto the market tend to depress the value of the commodity, and therefore help the short contract, it also gives her an opportunity to threaten to actually deliver the commodity in the future. A large number of commodity traders may not actually want to own the commodity; they may be pure speculators, or perhaps they are using the commodity as a proxy for some other hedging purpose. For example, a farmer, afraid that synthetic fertilizer costs may go up with energy prices, could buy oil futures without actually wanting to receive oil. If she is forced to take delivery, she is likely to sell the oil quickly. If the manipulation is successful, a selling spree may be touched off by longs rushing to liquidate or retender deliveries received at increasingly lower prices. $^{47}$ A short-squeeze may be difficult to carry out because it often requires substantially more capital than long manipulations and is unaided by development of natural conditions such as natural squeeze. ${ }^{48}$ A crucial risk in the short squeeze is the possibility of large longs in the market with the capacity to "stop" delivery (i.e., take delivery of the physical commodity). If the short dumps cheap oil into the market, but someone is ready to receive the oil, the short will lose substantially.

\section{Legal Standard of Manipulation}

For all that, the law has long prohibited manipulation. It is common to say, with the CFTC, that four elements make up a CEA manipulation: (1) a manipulative act or omission; (2) intent; (3) causation; and (4) artificial

46. Easterbrook, supra note 21 , at $\mathrm{S} 106$

46. Easterbrook, supra nos. [1975-1977 Transfer Binder] Comm. Fut. L. Rep. (CCH) 20271, at 21477 (CFTC Feb. 18, 1977) (quoting ThomAs A. Hieronymus, ECONOMics OF FUTURES TRADING 309 (1971)).

48. Russo, supra note 39, §12-16. 
price. $^{49}$ Commodities manipulation law has not looked to fraud or deception directly, unlike the securities regime. Instead, this four-part test focuses on market-power manipulation, typically the result of trading.

The legal and evidentiary standards for these elements are, in large part, the subject of subsequent sections (other than manipulative acts, which we considered, in part, above). It is common for investigations and trials to concentrate on causation and artificiality of price together, on the one hand, and intent on the other. This section elaborates the ways in which these standards are implemented with an emphasis on the use of econometric proof.

\section{Price Artificiality and Causation}

Price artificiality has been called the sine qua non of manipulation. ${ }^{50}$ An artificial price is one that does not "reflect basic forces of supply and demand." ${ }^{51}$ Where prices are artificial, they do not reflect all possible market factors and create "conditions which prevent the futures market from performing its basic economic function and hence [diminish] its utility to those members of the trade and general public who rely on its basic purposes." ${ }^{152}$ But manipulations that fail to create an artificial price have generally not been a concern since, "[i]t is generally considered that none of [the evils of manipulation] occur absent distorted or artificial prices." ${ }^{53}$

Artificiality has been essential, in part, to focus enforcement where harm has been done. The manipulator must have caused the artificial price, but she need not be the singular cause of the artificial price: "It is enough, for purposes of a finding of manipulation in violation of section $6(\mathrm{~b})$ and 9 of the $[\mathrm{A}] \mathrm{ct}$, that respondents' action contributed to the price [movement]." ${ }^{, 54}$

49. In re Cox, [1986 Transfer Binder] Comm. Fut. L. Rep, (CCH) 23,786 at 34,06 (CFTC July 15, 1987); see also In re Amaranth Natural Gas Commodities Litig., 587 F. Supp. 2d. 513, 530 (S.D.N.Y. 2008); Russo, supra note 39, at \$12-11. As pointed out below, the respondent does not have to be culpable of the entire difference between artificial and the market prices that would have prevailed under manipulation. In re Kosuga, 19 Agric. Dec. 603, 624 (U.S.D.A. 1960)

50. Craig Pirrong, Commodity Market Manipulation Law: A (Very) Critical Analysis and a Proposed Alternative, 51 WASH. \& LEE L. REv. 945, 956 (1994).

51. Cargill, Inc. v. Hardin, 452 F.2d 1154, 1163 (8th Cir. 1971), quoted in WiLliams, supra note 14 , at 6 .

52. Cargill, 452 F.2d at 1158

53. Russo, supra note 39 , at $\$ 12-22$.

54. Great W. Food Distribs., Inc. v. Brannan, 201 F.2d 476, 483 (1953) ("[F]resh eggs sell at a reasonably constant premium of considerable size over cash refrigerator eggs and refrigerator futures, and that, generally, the prices of cash refrigerator eggs and refrigerators
Although some scholars question the coherence of a notion of "artificial price," ${ }^{55}$ all agree that artificiality is not self-evident. Hence, from the beginning, artificiality was in need of proof and courts have often allowed use of econometric analysis. In Cargill, Inc. v. Hardin, a classic corner in the Chicago Board of Trade (CBOT) in bushels of wheat, the plaintiff's expert proposed four tests for artificial prices characteristic of a squeeze ${ }^{56}$ three of which constitute an historical analysis of past price squeeze, 57: (i) anayzing he allegedly atificial price movemt in light movements ${ }^{57}$ : (i) analyzing the allegedly artificial price movement in light of price movements in the past nine years; (ii) comparing the spread between the allegedly manipulated future and the next closest future and comparing its movement to spreads over the previous nine years; (iii) evaluating the exchange traded futures prices with equal futures on other evaluating the exchange trationship exchanges as compared to prior years; and (iv) determ to delivery with cash between prices. $^{58}$

The price artificiality inquiry need not be limited just to price trends: The viability of manipulation often depends on the knowledge of market participants and the structure of the market. Judge Easterbrook explains the Court's decision in finding Cargill liable for manipulation: "Cargill had used its special knowledge to advantage-it profited not because it knew more about the demand and supply of wheat in the cash market but because more about the demand and supply of wheat in the cash market

Judge Easterbrook goes on to point out the simultaneity of price spikes futures will reflect precipitous drops in the prices of fresh eggs. This testimony was corroborated by statistics dealing with these relative prices ding Russo points out that the court neglected to subject the statistics to any significance tests. Russo, supra note $39, \S 12-26$.

55. Easterbrook, supra note 21.

56. The CFTC in In re Indiana Farm Bureau overturned a prior court decision stating that the "historical price comparisons of the type relied upon by the courts in Cargill and G.H. Miller are value here because of the unique combination of G.H. Miller are on the corn pit on July 20, 1973." In re Indiana circumstances wher 27,281 (CFTC Dec. 17, 1982).

27,281 (CFTC Dec. 17, 1982). 57. The same comparisons were also suggested in a 52 (1921). It is noted that "[t]he grain market. 5 FTC, Report on the Grain Trade 27,52 (1921). It is noted that " existence of a corner may not, however, be completely revealed by this methodology because other market supra note 1 , at 294 .

58. If the futures market is functioning properly, at the close of trading in the futures, 58. the price of the futur delivery (Cargill, Inc. v. Hardin, 452 F.2d 1154 ). See JOHN C. HULL, OPTIONS, Futures,

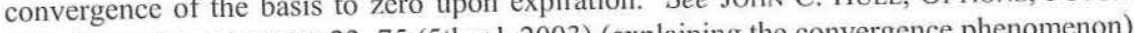
AND OTHER DERIVATIVES 23, 75 (5th ed. 2003)

59. Easterbrook, supra note 21, at S119. 
and a large long open position does not necessarily constitute fraud and is therefore not considered manipulation if other traders knew about the open position. Similarly, Markham points to a Federal Trade Commission ("FTC") study where "it [is] noted that natural squeezes and corners generally relate to the peculiarities of the futures markets rather than to supply and demand conditions," economic analysis on the but-for price to assist in the determination of an artificial price, and on the possible causes of such effect. Indeed, Judge Easterbrook suggests some of the analyses that an economist should undertake when dealing with an alleged manipulation. He writes:

Someone searching for manipulation might look for asymmetric information. He also might look for the telltale sign of sudden price fluctuations. When the closing price on a futures contract significantly diverges from the price of the cash commodity immediately before and after, this is strong evidence that someone has reduced the accuracy of the market price and inflicted real economic loss on participants in the market. Courts usually look for both concealment and sudden swings in price. ${ }^{61}$

In 1953, in Great Western Food Distributors, Inc. v. Brannan, ${ }^{62}$ the court found manipulation on the grounds that egg futures prices did not drop to a normal relationship with fresh eggs and other egg prices. ${ }^{63}$ The court looked at three instances to show that prices had been manipulated and were artificially high. First, the government showed that the supply of refrigerated eggs in the allegedly manipulated December 1947 contract was higher than it had been in two previous months as well as in December of 1946. It further showed that real demand, as opposed to technical demand created by a cornering operation, was lower in December 1947 than in the previous months. The court rejected the foregoing evidence stating that the government failed to prove similar market conditions and prices in the comparative months. Second, the plaintiff provided evidence of the historical spread relationships between December and January futures at the close of trading in the December futures during the years 1932-1948 (excluding some observations where price controls were in effect) and compared it to the allegedly manipulated December 1947 futures. Third, the court looked at the excessive premium of cash to futures eggs in light of a historical constant premium that existed even during volatile price episodes. $^{64}$ In this case, proof that prices were manipulated or artificially

60. Markham, supra note 1, at 294

61. Easterbrook, supra note 21, at S118.

62. 201 F.2d 476 (7th Cir. 1953).

63. Id. at $482-83$.

64. Id. enhanced was perhaps the main issue in the entire proceeding.

In In re Compania Salvadorena de Café, collusive manipulation was found when Salvadorena took delivery of about eighty-four percent of July 1977 coffee contracts. The Commission argued that objective measures fid not actually need cash coffee and compared found that Salvadorena did not actually need cash coffee and compared coffee prices to relevant benchmarks in similar coffee futures. The administrative law judge concluded that an artificial price resulted from these activities because the July contract prices exceeded the International Coffee Organization indicator price for coffee of equivalent grade and Cor the September 1977 contracts. As one of the coauthors of this Article, Ms. Abrantes-Metz, has explained in a previous paper:

In the silver manipulation episode of $1979-1980$ by the Hun Brothers, nine economists (seven of which testified) prepared reports on the silver market. Defense side experts opined on the political and economic interpretation of the rise in prices, and presented analyses on the prices in silver futures for distan prescnted analyses on the price in wich delivery dates as evidenc with the Hunts trading. Evidence on price relationships, comparing silver to other metals including gold and bullion to coins was also presented on the defense side. A variety of tests for price artificiality and causation were applied, for example by comparing silver and gold prices and using "Granger-causality" tests to determine whether the trading in silver had influenced to distinguish the Hunts' trading from other possible influences on silver by relating the daily changes in their positions to the daily changes in the prices of silver, and found no statistically significant effect from the Hunts' trading. They also presented correlations among bullion price to show the geographic extent of the market and introduced evidence on price relationships from several other markets. ${ }^{66}$

The plaintiff's economic experts presented statistical studies of silver prices to comparisons of the Hunts' futures position with bullion in

65. "Salvadorena had a policy of using the futures market to help support coffee prices during at least 1976 and $1977 \ldots$... Salvadorena, the National Federation of Columbian Coffee Growers, the Mexican Coffee Institute, and the Brazilian Coffee Institute had Coffee Grounds to support coffee prices." In re Compania Salvadorena De Cafe, [1982contributed (citation omitted)

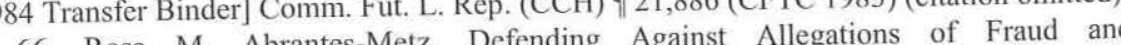

66. Rosa M. Abrantes-Metz, Defending Against Allgatons Manipulation: The Role of the Economist under the New CrTC Rules (Jan. 9, 2012) (unpublished manuscript), available at http://papers.ssrn.com/sol3/papers.cfm?abstract_id= 1982302 
exchange-approved vaults. Attention was also drawn to specific acts, such as the deliverables taken, as evidence of manipulative intent. The plaintiff's experts analyzed the following indicators, which they argued flagged manipulation: the silver/gold ratio, the coin/bullion differential, the price spread with more distant delivery dates, and the variability of prices.

Williams presents a very detailed description of all of the economic and empirical analyses performed, their advantages, and limitations. ${ }^{67}$ Economists presented analyses addressing all of the relevant four-part tests of manipulation, and as Williams describes:

The two weeks that the economists spent before the jury represented the lengthiest testimony except for that of the Hunts themselves. The economist expert witnesses addressed all the key aspects of any civil case, namely the nature of the offense, the defendants' intent to commit the offense, the causal connection between the defendants' actions and the damage to the plaintiff, and the monetary valuation of that damage. The economists spoke to the "ultimate issue": Did the Hunts manipulate the silver market?"68

At the end, Judge Morris E. Lasker had few doubts in determining that the Hunts and their allies were the cause of the skyrocket pricing pattern observed. Prior to the Hunt Brothers' episode, it was thought that the silver market was too large to be manipulated, but this decision showed that the Hunts accomplished what previously had been thought to be not feasible.

Turning from silver to copper, Gilbert suggests that when searching for manipulation "one may look for distortions in the futures price structure (ie the term structure of futures prices) which are not explicable in terms of seasonality." ${ }^{69}$ Backwardation, defined as a negative value for the difference between the futures price of a contract and the cash price for the same commodity, has been identified as potentially indicative of manipulation. Though backwardation can never be conclusive evidence of manipulation, "if a market becomes abnormally prone to move into backwardation, manipulation may be presumed."70 Under backwardation, there tends to be a high basis (structure) variability resulting in a poorer

67. Williams, supra note 14 , at 100-60.

68. Id. at 12

69. Gilbert, supra note 22, at 6; see also Russo, supra note 39 \$ 12-23, ("Although the maximum price difference for more distant months over nearby months is a virtual certainty, the reverse is not always the case. When a severe shortage of deliverable commodities exists, whether for natural reasons or because the market prices are being manipulated, the exists, whether for natural reasons or because the market prices are being manipulated, the
arbitraging activities of commercial users described above are inhibited and the cash and nearby futures trade at premiums over subsequent delivery months."). Note that such a convention only applies to non-perishable commodities.

70. Gilbert, supra note 22, at 7 quality hedge. Of course, other circumstances could cause high volatility in prices and consequent backwardation. It follows that if stocks (supplies) are sufficiently available, backwardation would be unexpected. Gilbert states that only under these circumstances would highly variable backwardation be indicative of manipulation. Vice versa, "it is difficult to distinguish attempted manipulations from successful speculation in a bull market.",11

Gilbert uses the Sumitomo episode regarding an alleged manipulation of copper in the 1990's on the London Metal Exchange (LME) to conclude that an observed stark backwardation in the futures term structure is potentially indicative of manipulation. ${ }^{72}$ In the case of Sumitomo, manipulation was alleged to have lasted for a period of over six years, and the CFTC also alleged that backwardation was so extensive and longlasting on the LME that copper supplies moved from the COMEX warehouse in Arizona to the LME warehouse in California. ${ }^{73}$ Furthermore, the CFTC argued that arbitrage trading and other factors linked trading of copper on the COMEX with that on the LME and Sumitomo's activity caused the upward manipulation of copper futures prices on the COMEX. ${ }^{74}$ Thus, distortion of prices can, under certain conditions, spread to other markets or to other exchanges, which should be considered in a comparative price analysis.

\section{Intent}

Although some scholars argue that the harms of manipulation are sufficiently indicative of such behavior that they warrant remedy even absent a demonstrated intention to manipulate, ${ }^{75}$ it is clear that manipulation liability is never incurred unintentionally. ${ }^{76}$ Importantly, manipulation does not occur by simply trading in a manner that affects the price. The scienter requirement articulated in In re Indiana Farm Bureau makes clear that more is required: "the intent requirement, which is the same for a manipulation and an attempted manipulation, is 'the performance of an act or conduct which was intended to effect an artificial

71. Gilbert, supra note 22, at 9 .

72. Gilbert, supra note 22 , at 7-10

73. In re Sumitomo Corp., CFTC Docket No. 98-14 (CFTC May 11, 1998).

74. Id. at $* 18$

75. For ex Pirrong, supra note 50; Fischel \& Ross, supra note 28 .

76. See Markham, supra note 1, at 284 (observing that "the government and the courts have engrafted an intent requirement onto the prohibition against manipulation, requiring a showing that the trader intended to create an artificial price") 
price." "77 That is, scienter in manipulation law is intent as to the artificial price element. The Cargill court concluded that " $\mathrm{t}]$ he aim must be ... to discover whether conduct has been intentionally engaged in which has resulted in a price which does not reflect basic forces of supply and demand." ${ }^{78}$

A requirement of intention is important because it is widely believed that some arrangements with manipulative effects can occur by accident For example, a market actor may buy a quantity of futures as well as the underlying commodity, and then the supply of the underlying commodity may decline for unrelated reasons. She would find herself with a right to demand delivery from counterparties while, quite innocently, she owns much of the existing stock of the commodity. The law regards this accidental corner quite differently from one that the trader intentionally effected. In Great Western Food Distributors v. Brannan, ${ }^{79}$ which concerned manipulation of the market price of refrigerated eggs, the court declared that "the intent of the parties during their trading is a determinative element of a punishable corner" and unintentional corner should not carry the same penalties. ${ }^{80}$ Similarly, in Volkart Brothers $v$ Freeman, the Fifth Circuit, considering a squeeze in the New Orleans Cotton Exchange, recognized that squeezes may be mere congestions and thus, it must be proven "that [the respondents] intentionally brought about the squeeze by planned action." accidental transactions would be subject to liability. ${ }^{82}$

Although specific intent is required under the CEA, courts have allowed proof by way of circumstantial evidence or by showing that the defendant had both the motive and the opportunity, as with securities fraud law. ${ }^{83}$ Objective econometric analysis therefore plays an important role in establishing subjective state of mind. For example, the Cargill court, considering unusual trading patterns at the end of a trading day, found that Cargill's "behavior in liquidating its contracts was clearly intentional and

77. [1982-1984 Transfer Binder] Comm. Fut. L. Rep. (CCH) ๆ 21,796, 27,282 (CFTC Dec 17, 1982) (citation omitted)

78. Cargill, Inc. v. Hardin, 452 F.2d 1154, 1163 (8th Cir. 1971)

79. 201 F.2d 476 (7th Cir. 1953).

80. Id. at 479 .

81. Volkart Bros., Inc. v. Freeman, 311 F.2d 52, 59 (5th Cir. 1962)

82. See Markham, supra note 1, at 320 ("[T] charging of what someone may consider to be an unreasonably high price.... A squeeze not planned or intentionally brought about by a trader would not be actionable under the Commodity Exchange Act.")

83. Cargill, 452 F.2d at $1167-70$. Such inference of intent is in agreement with Perdue's definition of manipulation "as conduct that would be uneconomical or irrational, absent an effect on market price." Perdue, supra note 19, at 348 . was highly unusual market behavior; and the method of liquidating the in close of trading was also unusual unresolved opent explanation for unusual behavior.

Courts will sometimes infer that actions taken contrary to apparent commercial interest are indicative of intention to manipulate. The notion of commercial interest was also addressed in In re Sumitomo, where traders for Sumitomo "acquired and maintained a dominant and controlling position in both the physical supply of deliverable LME warehouse stocks and in maturing LME futures positions." positions were not intended to meet Sumitomo's legitimate commercial needs," but rather "[t]he intent motivating the acquisition and control of both the cash market positions and the futures market positions was expressly to create artificially high absolute prices and artificially high and distorted premium of nearby prices over futures prices." 86 Further, "[a]s distorted premium of nearby prices over future is affected by a factor which is not legitimate, the resulting price is necessarily artificial."

Circumstantial proof of intention may include profit motive, ${ }^{88}$ tying up delivery and/or transportation facilities; ${ }^{89}$ establishment of substantial futures and cash positions and subsequent disposition of those positions, particularly if not consonant with ordinary commercial behavior; ${ }^{90}$ use of particularly if not consonant with ordinary commercial behavior, use of step-up orders; and payment of prices in excess of to exclude legitimate This is typically combined with appropriate analysis to exclude legitimate reasons for such actions, which is both a key legal dimension of manipulation law and one in dire need of economic analysis to be properly conducted. Finally, Russo observes that a long who takes advantage of a conducted. Finally, Russo "by standing for delivery can rightfully be said to natural squeeze in supply In such a case, a passive investor, upon learning of the squeezed market

84. Cargill, 452 F.2d at $1170-71$.

85. In re Sumitomo Corp., CFTC Docket No. 98-14, at *17 (CFTC May 11, 1998).

86. $I d$.

87. Id. at * 18

88. Cargill, Inc. v. Hardin, 452 F.2d 1154 (8th Cir. 1971); In re Hohenberg Brothers, 1975-1977 Transfer Binder] Comm. Fut. L. Rep. (CCH) 20271, (CFTC Feb. 18, 1977); In re Indiana Farm Bureau Coop. Ass'n, Inc., [1982-1984 Transfer Binder] Comm. Fut. L. Rep. (CCH) 21,796 (CFTC Dec. 17, 1982)

89. As alleged by plaintiffs in Leist v. Simplot, 638 F.2d 283, 290 (2d Cir. 1980); Russo, supra note $39, \$ 12-20$.

90. Cargill, 452 F.2d 1154

91. Id.

92. In re Henner, 30 Agric. Dec. 1151, 1232-39 (U.S.D.A. 1971); see also Russo, supra note $39, \S 12-20$.

93. Russo, supra note $39, \S 12-34$. 
conditions and deciding to act on this knowledge, becomes an active manipulator.

\section{Manipulation is Hard to Prove}

Over the last several decades, the CFTC has not successfully prosecuted a meaningful number of manipulation cases. ${ }^{94}$ Many agree that its lack of success in litigation has been due in great part to the fact that in order to establish manipulation, the CFTC was required to prove the intent to create an artificial price, that prices were in fact artificial, and that they were caused by the alleged manipulator. As one scholar has noted:

$[U]$ nder present law the crime of manipulation is virtually unprosecutable, and remedies for those injured by price manipulation are difficult to obtain. Moreover, even where a prosecution is successful, the investigation and effort necessary to bring a case will involve years of work, enormous expenditures, as well as an extended trial. ${ }^{95}$

The difficulty of proving manipulation as a conceptual matter has been discussed above, but its practical difficulties are best illustrated by the financial market's most shocking contemporary manipulation-Libor.

\section{Libor}

Libor has been called "the world's most important number,"96 and it dominates the interest-rate swap market ${ }^{97}$ and syndicated loan market, ${ }^{98}$ and

94. Dissatisfaction with the CFTC has been noted by members of Congress and in case law. See, e.g., Commodity Futures Improvements Act of 1991. Hearing on H. R. 707, case Cong. 212 (1991); 135 CONG. R C. H5603, H5613 (daily ed. Sept. 13, 1989) (stan, 102nd Rep. Long) ("I feel that we should do all that we can to cu. Sept. 13, 1989) (statement of active role in reguting the exchas ..."); Am. active role in regulating the exchanges .....); Am. Agric. Movement, Inc. v. Bd. of Trade of Chi., 977 F.2d 1147, 1166 (7th Cir. 1992) ("[T]he amendment was motivated in large part by dissatisfaction with the Commission's failure to take vigorous action in this very case.... A separate provision in both bills further reflects Congress' view that the Commission's supervision has been less than adequate.").

95. Markham, supra note 1, at 281; Pirrong, supra note 17, at 60 ("The reasoning in (t) three simultaneously.").

96. See sources cited supra note 7.

97. Dennis Kuo, David Skeie \& James Vickery, A Comparison of Libor to Othe Measures of Bank Borrowing Costs (June 2012) (unpublished manuscript), available a http://www.newyorkfed.org/research/economists/vickery/LiborKSV_staff_webpage.pdf.

98. Xanthe Lok, Libor and Market Disruption: The Future of Libor, 23 BUTTERWORTHS J. INT'L BANKING \& FIN. L. 421, 421 (2008). powerfully influences residential and commercial mortgages. ${ }^{99}$ The British Banker's Association (BBA)'s website states that Libor is the primary benchmark for short-term interest rates globally, and is used as the basis for settlement of interest rate contracts on many of the world's major futures and options exchanges. At least an estimated $\$ 350$ trillion worth of contracts reference Libor. ${ }^{100}$

Early in 2011, it became public that the U.S. Department of Justice, the Securities and Exchange Commission (SEC), the CFTC, the Japanese FTC, the European Commission and other regulatory agencies ${ }^{101}$ had started investigating the possibility of a conspiracy between traders and treasury departments of several major banks aimed at manipulating Libor in various currency denominations between at least 2006 to at least 2008 . In June of 2012, Barclays detailed how its traders had attempted to manipulate Libor since at least $2005,{ }^{102}$ for which Barclays paid a settlement of $\$ 450$ million - then the largest fine ever levied by the U.S. and U.K. regulators. ${ }^{103}$ In addition to these governmental investigations, there is significant private litigation activity currently in its initial stages.

During the period of time corresponding to the allegations, Libor operated by way of sixteen banks submitting sealed daily quotes, and the "middle 8" quotes (in terms of value) being converted into the Libor through a simple arithmetic mean calculation. The Libor quotes are submitted by an employee of each of the contributor banks, just before 11

99. Justin T. Wong, Libor Left in Limbo: A Call for More Reform, 13 N.C. BANKING INST. $365,365(2009)$ (stating that Libor is the reference rate for $\$ 900$ billion in subprime mortgages); Carrick Mollenkamp, Serena Ng. Laurence Norman \& James Hagerty, LIBOR's Rise May Sock Many Borrowers, WALL ST. J., Apr. 19, 2008, at B1

100. Kuo et al, supra note 97; The Basics, BBA LiBOR, http://www.bbalibor.com balibor-explained/the-basics ("bbalibor . . . is written into standard derivative and loan /bbalibor-explained/he-bas IS terms, and is used for an increasing range of retail products documentation such as he such as mortgages and college loans. .... It is the basis for settlement

contracts on many of the world's major futures and options exchanges.").

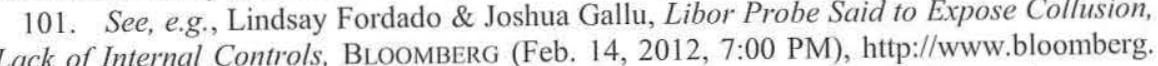
Lack of Internal Controls, BLOOMBERG (Feb. 14, 2012, 7:00 PM), http://www.bloo controls.html.

102. Non-Prosecution Agreement, Appendix A, Statement of Facts (June 26, 2012) 102.

103. Lindsay Fortado \& Silla Brush, Barclays Fined by U.K. U.S. for Falsifying Libo 103. Lindalom Rates, BLoOM (June 27, 2012, 3:3 PM), Since that time, UBS 27/barclays-said-to-be-nearing-hibor-settement-wih-fsa-cfc.he paid about $\$ 1.5$ billion, and Royal Bank of Scotland paid about $\$ 600$ million. Danielle Douglas, Royal Bank of Scotland to Pay \$612 million to Resolve Libor Case, WASH. POST, Feb. 6, 2013, http://www.washingtonpost.com/business/economy/rbs-to-pay-612m-toresolve-libor-case/2013/02/06/2c0cc42c-6fd3-1 le2-aa58-243de81040ba_story.html?wprss= rss business. 
a.m. each day, in response to the following question: "At what rate could you borrow funds, were you to do so by asking for and then accepting inter-bank offers in a reasonable market size just prior to 11 am?"104 The quotes are supposed to reflect the rate at which large banks can borrow unsecured funds from other banks. On a daily basis, after all quotes are submitted and the Libor is computed, all of this information (including all individual quotes) is made public.

The alleged manipulation concerns the submission of knowingly inaccurate Libor quotes by the panel banks. If several banks submit figures that do not closely match their actual borrowing costs in the interbank market, then the aggregate Libor is probably affected.

Three theories are often discussed with respect to the alleged motive of the banks in this matter. The first is a reputational theory, according to which several of the panel banks artificially depressed the price of Libor by submitting falsely low quotes, in order to preserve their reputations during the early days of the financial crisis. Submitting a quote to the BBA that showed a very high borrowing cost in the interbank market might indicate that the market is unsure of that bank's creditworthiness, which could result in worsening financing prospects. No bank wanted to be the next Lehman Brothers or Bear Stearns, so each had an incentive to lowball their Libor quote. Libor itself would consequentially end up too low.

The reputational theory seems to be the most well-known, having been the subject of the Wall Street Journal article that brought the possibility of a Libor disruption to public attention, ${ }^{105}$ but plaintiffs in the various lawsuits generally rely on a different theory. They posit that the panel banks were motivated by a desire to extort wealth from their customers. This extractive theory points to the fact that a disruption in the Libor would result in large wealth transfers, benefiting or harming anyone who had a non-zero net exposure to Libor. If Libor were artificially lowered, those who owed money on loans written to Libor would owe less to their lenders than before. Contracts that are settled in terms of Libor would be lower in value. For example, the CME Eurodollar futures contract settlement price is defined as one hundred minus Libor, ${ }^{106}$ so that a four percentile drop in Libor would result in a four percentile drop in settlement value to the purchaser.

The panel banks borrow or lend at Libor, and they may take positions in the Eurodollar contract market, but the most important means of

\footnotetext{
104. The Basics, BBA LiBor, supra note 100.

105. Mollenkamp, Libor Fog, supra note 7.

106. Eurodollar Futures, CME GRoup, http://www.cmegroup.com/trading/interestrates/stir/eurodollar_contract specifications.html (last visited Jan. 30, 2013).
}

extraction would have been by way of interest rate swaps. Interest rate swaps are a massive market approaching $\$ 450$ trillion dollars in notiona swaps are a massive mare a party to eighty-two value ${ }^{107}$ in which the fourteen largest dealers are a party to eighty-two percent of the transactions by value. Libor panel banks are among the largest swap dealers in the world. ${ }^{108}$

Interest rate swaps allow corporations, commercial banks, and other entities to manage their interest rate risk. For example, the City of Baltimore has entered into many swaps in which it pays a fixed rate and Baltimore has entered into many swaps in was the city paying $4.97 \%$ to their receives Libor. One 2003 swap has the city paying $4.97 \%$ to their counterparty and receiving the one-month Libor rate. ${ }^{99}$ This \$17 million swap makes the city better off when interest rates rise, which is intended to help the city cope with its floating rate bonds, which become more expensive as interest rates rise.

In a typical interest rate swap, one party pays a fixed amount and the other pays an amount linked to a varying rate such as Libor. Generally, derivatives dealers will try to have something like a balanced position, ffering a floating rate in one contract and receiving a floating rate in another. That way they are not caught off-guard by the vagaries of interest another. That was in position position cane the Libor receiver, it would bene reduce Baltimore's City of Baltimore, a decline in the Libor rate would reduce Baltimore's payment from its counterparty while its fixed-rate obligation remained payment from it would have accrued wealth from the manipulation. The extraction theory, would have accinte offered by the plaintiffs of the fact that they had robust net positions on Libor.

A final theory is related to the extraction theory, but it does not

107. ISDA Market Survey, ISDA.ORG (2009), http://www.isda.org/statistics/pdf/ISDAMarket-Survey-historical-data.pdf.

108. Participants in the Mid-Year 2010 ISDA Market Survey, ISDA.ORG, 108. Participants in http://www.isda.org/statistics/pdf/Participants-MY

the 71 banks that contribute to the ISDA survey). 109. City OF Baltimore, COMPre JUNE 30, 2009, at 58 (March 31, 2010).

110. If Baltimore's bonds are all linked to Libor as well, then the city may not net a los or gain, but its bondholders would lose from a lower Libor.

111. In re LIBOR-Based Fin. Instruments Antitrust Litig., No. 11-MD-2262, 2011 WI 5980198 (S.D.N.Y. Nov. 29, 2011).

119 Libor Reflect Banks' Borrowing Costs? 112. Connan Snider \& Thomas Youle, Does the Libor libor 4 01 10.pdf. 
imagine long-term and large positions on a bank's balance sheet. Rather, the trading theory suggests that a bank may have engaged in trading that was informed by their knowledge of future Libor changes, or that they may have changed Libor to benefit short term trading positions. This theory is closer to ordinary insider trading. No vocal proponent has endorsed this view, though it does fit the tone of allegations against a recently dismissed trader from the Royal Bank of Scotland's Singapore office. Tan Chi Min alleges in his wrongful termination suit that it was common practice for senior bank employees to request that RBS seek to influence the Libor rate to profit their own positions as well as those of the banks. ${ }^{113}$ One could imagine traders treating Libor as their secret weapon to make sure that Eurodollar futures trades work out well more often than they should.

This last example underscores an important point: If any manipulation occurred, it may or may not have had institutional approval. Tan claims that it was RBS's practice to influence the Libor, but his employer claims that Tan was fired for improperly influencing Libor on his own initiative. On any theory, a manipulation might have been perpetrated by a rogue trader or executive rather than with the full approval of the board of directors.

Nonetheless, even the lone wolf theory in which a trader acts alone calls into question a bank's internal controls. Regulators in Japan recently sanctioned Citigroup and UBS because their employees attempted to improperly, and repeatedly, influence the Tibor (the Tokyo equivalent of the Libor). ${ }^{114}$ The Japanese Securities and Exchange Surveillance Commission said that the banks lacked internal controls to prevent rate manipulation. $^{115}$ Barclays' non-prosecution agreement included lurid descriptions of traders and rate-setters, sitting nearby one another or cozily agreeing to cooperate. ${ }^{116}$ The FSA's subsequent investigation concluded that "[t]here are weaknesses in governance arrangements for the compilation process, and within contributing banks themselves."

The result of potential manipulation could be monumental. Consider

113. 2nd UPDATE: Ex-RBS Singapore Trader Sues Bank For Wrongful Dismissal, WSJ.COM (Jan. 12, 2012, 10:22 AM), http://online.wsj.com/article/BT-CO-20120112709529.html; see also Caroline Binham et al., Brokers Suspended in Libor Inquiry, FIN. Times, Feb. 9, 2012, at A1.

114. Hiroko Tabuchi, Japan Calls for Action Against Citigroup and UBS, N.Y. TIMEs DEALBOOK (Dec. 9, 2011, 7:29 AM), http://dealbook.nytimes.com/2011/12/09/japan-callsfor-action-on-citigroup-and-ubs.

115. Id.

116. See supra note 102 .

117. The WheatLey ReVIeW of LIBOR: Final Report 75 (HM Treasury, UK Sept. 28 2012); see also id. at 81 (explaining how Barclays failed to have adequate risk managemen or controls).
Libor's impact on real estate. One study by the Federal Reserve of Cibor hovered $1.75 \%$ higher than Cleveland found that if the six-monter as it did in early 2008 , then the average subprime borrower would pay an additional $\$ 100$ per month, per $\$ 100,000$ of remaining debt ${ }^{118}$ Thus, a modest manipulation upward in Libor could easily extract \$1000-2000 per year from a typical subprime borrower. Regressive by any standard, this would increase mortgage defaults at a time when they already pose systemic risk concerns. Individual wealth transfers can lead to inefficient capital allocation and systemic risks:

A lower Libor induces a lower mortgage rate, makes it easier to buy homes, substituting homes away for other goods. This artificially inflates the prices of homes... while deflating the the immediate implications of a nonprices of other goods. The immediate implications of a nonmarket determined Libor, over a prolonged period of time, have the potential to lead to bubbles and meltdowns of the type we are currently experiencing. ${ }^{119}$

A manipulated Libor would affect wealth transfers and misallocate apital. The index would also eventually lose respectability in the marketplace, which would be a tragedy. The Association of Corporate Treasurers, once a critic of the banks alleged to have manipulated Libor, ${ }^{120}$ Treasurers, once a critic of the banks alleged to have Libor banks. ${ }^{121}$ Though potentially victims of any manipulation, corporate borrowers enjoy having por franca for borrower rates, and would be genuinely harmed if Libor a lingua franca for borrower
lost widespread credibility.

We discuss in a later section some of the means used to screen for potential manipulation and conspiracy in this market. The immediately following section goes on to show the challenges that would be expected in bringing a suit against the panel banks under pre-Dodd-Frank manipulation law even if the allegations were true. If the Libor disruption represented manipulation, the pre-Dodd-Frank CEA would be ill-equipped to remedy the manipulation.

18. Mark Schweitzer \& Guhan Venkatu, Adjustable-Rate Mortgages and the Libor 118. Mark Schweitzer a available at $\mathrm{http}: / / \mathrm{www}$.clevelandfed.org/research/commentar

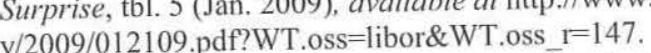

119. Rosa Abrantes-Metz et al., Tracking the Libor Rate, 18 Applied Econ. LetTers 893, 897-99 (2011).

20. Press Release, Ass'n of Corp. Treasurers, Loan Agreement Market Disruptio 120. Press to be Invoked only as a Last Resort (Sept. 28, 2008), Clauses tor trestion/pressrelease.

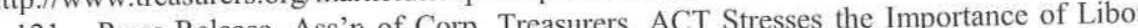
121. Press Release, Ass'n of Corp. Treasu hor //www treasurers org/node/7329. and EURIBOR to companies, (Oct. 24, 2011), http://www.treasurts.org/node/7329. 122. Author's conversation with John Grout, Policy \& Technical Director, Association
of Corporate Treasurers (Nov. 9, 2011). 
1. Problems of Proof

Before Dodd-Frank, manipulation law required proof of price artificiality and the defendant's intention. These are difficult elements to prove, and they are particularly difficult with a financial instrumentality like Libor. Below, we apply these elements to Libor with a focus on the role of economic analysis.

\section{a) Artificiality}

Notwithstanding the longstanding use of empirical investigation in manipulation cases, described in I.C., supra, adjudicators have sometimes tied their hands by being hostile to econometric means of proving artificiality. ${ }^{123}$ Indiana Farm Bureau provides a particularly clear example. ${ }^{124}$ Although a $30 \%$ price jump on the last day of corn trading was enough to persuade two Commissioners of price manipulation, the majority dismissed the use of cash-futures price comparisons. ${ }^{125}$ The result has been a very high standard of proof with very little means of realistically attaining it. $^{126}$ However, some scholars have concurred in skepticism about the possibility of inferring artificiality from a benchmark of comparable prices. $^{127}$

These problems become vastly more difficult when confronting interest rates rather than eggs. If $30 \%$ price jumps in eggs are unimportant to a court, then some very profitable manipulations will fly below the court's radar.

One reason concerns scale. For many commodity and swap transactions, the profits reaped from manipulation could be great even when the relative scale of manipulation is small. The notional value indexed to Libor approaches $\$ 400$ trillion. A tiny change in Libor produces

123. See, e.g., Pirrong, supra note 50 (examining existing decisions which have restricted the use of econometric means in proving manipulation).

124. In re Indiana Farm Bureau Coop. Ass'n, Inc., [1982-1984 Transfer Binder] Comm. Fut. L. Rep. (CCH) ๆ 21,796 (CFTC Dec. 17, 1982).

125. Id. ๆf 27,286-87; accord In re Cox, [1986 Transfer Binder] Comm. Fut. L. Rep. (CCH) ๆ 23,786 at 34,064 (CFTC July 15, 1987) ("'[T] he prospective behavior of a 'normal' market is not necessarily bounded by the market's historical experiences.").

126. See Pirrong, supra note 50, at 959 (explaining that "current precedents make it extremely difficult to find a trader guilty of manipulation even in cases in which the economic analysis suggests that the trader has indeed manipulated").

127. See JOHNSON \& HAZEN, supra note 12, at 1262 ("It seems fair to say that no two futures contracts behave identically, and even when similar futures exist, they may be occasioned by quite different market conditions or judgments."); Lower, supra note 1, at 394-96; McDermott, supra note 15; Perdue, supra note 19, at 373-80; Van Smith, supra note 25 simply massive transfers of wealth. For example, some have suggested that simple thirty basis points. ${ }^{128}$ If Libor were to thirty basis points. If Libor were to move down thirty basis points, or $0.3 \%$, Libor payers in aggregate would see their liabilities drop by more than $\$ 1$ trillion per year. If large banks see their liabilities drop benefit. were net payers on wibor on $10 \%$ of the world's If, for example, a bank were a payer interest rate swaps by value, and a payee of Libor on $\%$ of the world's interest rate swaps, their net exposure would be $1 \%$ of the world's notional value, or $\$ 4$ trillion. Paying $0.3 \%$ less on that $\$ 4$ trillion exposure would value, or bank's share of the misallocation exceed $\$ 10$ billion annually, make coused by a relatively small manipulation. These back-of-the-envelope estimates are within the manipulation. These back-or-the-envelope 2009 reported that it would ballpark of the banks' own guesses. Citi in 2009 reported that it would make $\$ 936$ in net interest revenue if interest rates dropped twenty-five basis points per quarter for one year. ${ }^{129}$ These gradual changes are a fraction of the magnitude of the sudden price changes disregarded in Indiana Farm Bureau. An extractive manipulation could be vastly profitable and yet within the realm of statistical error, and well below the threshold a court might demand.

The relative profits could be even greater on a trading theory. If a trader could consistently guess the tiny movements in Libor, or cause them in With many trades per day, a bank's proprietary trading desk could leverage With many trades per day, a bank's proprietary dollars in a day. ${ }^{130}$

Courts cannot assume that a manipulation large enough to temp Conipulators will also be large enough for demonstration in court. Indeed, manipulators will also be large enough for the difficult to detect at profitable mard to show that a small change in the all. Once discovered, it may be hard to show that a sme; therefore, price was not the result of chance or some materiality of the alleged behavior may be difficult to establish. Unles reliable means can be used to find and locate the causes of true changes in the price of a swap or commodity, detection and proof will be rare and spotty.

\section{b) Intent is Hard to Prove}

For a plaintiff alleging manipulation, proving the defendants' intent

128. See Mollenkamp, Libor Fog, supra note 7 (reporting that an analyst at Citi 128.

129. Citi Form Y-9C.

Y note 113 (noting that hedge funds "place big bets on movements in [Libor] rates"). 
entails clearing many hurdles. Intent is a subjective state, which is not always readily demonstrable. While courts accept circumstantial evidence of intent from behavior, that behavior is often explicable without any intent, bedeviling the demonstration of the requisite scienter. If the investor has legitimate reasons for taking an action, then no manipulative intent can be concluded. ${ }^{131}$ As the judicial officer noted in In re Kosuga, "[d]rawing a line between legitimate trading and trading with manipulative intent is sometimes a very difficult task." 132 Since a small manipulation can still have a big impact, the trade or quote will not be far from what others would expect anyway.

It is always difficult to litigate mental states, but the legal burdens of demonstrating intent are exacerbated by certain features of financial law and financial markets because these industries promote the evaporation of typical forms of evidence of scienter. The Supreme Court has noted that "banking is a highly regulated industry,",133 and the more highly regulated an industry, and the more claims that are brought against participants in it, the likelier they are to avoid the sort of (electronic) paper trail to which plaintiffs have traditionally turned in seeking evidence of intent. For example, financial professionals now know that when matters become sufficiently problematic, they should call one another-on their personal cell phones - making smoking gun e-mails increasingly rare.

The In re Libor defendants may have left some documentary evidence if traders and brokers collaborated. ${ }^{134}$ The BBA excludes the top and bottom quartile of bank quotes, so that if any individual bank provides a "too low" or a "too high" Libor quote, it will be excluded by the determining group and hence will not directly influence the Libor. Yet

131. In re Indiana Farm Bureau Coop. Ass'n, Inc., [1982-1984 Transfer Binder] Comm Fut. L. Rep. (CCH) If 21,796 (CFTC Dec. 17, 1982) ("In the absence of evidence that respondents were responsible for the market congestion, it cannot be inferred that respondents' trading activity, consistent with their hedging program and commerci commitments, was intended to produce an artificial price. Standing for delivery as they did was respondents' contractual right and was motivated by the pre-existing com ascia did and the uncertainty of price in the inactive cash mot. Unlike Carill, I Bureau did not of price in the inactive cash market. Unlike Cargill, Indiana Farn Bureau did not delivery month; did no establish a large long speculative position at a time it knew it held virtually all of the cash commodity; and did not increase its long position on the last day of trading. Nor did it liquidate a dominant speculative long position at prices already seven to eight cents over the market.")

132. 19 Agric. Dec. 603,615 (U.S.D.A. 1960)

133. United States v. Phila. Nat'l Bank, 374 U.S. 321, 372 (1963).

134. Affidavit of Brian Elliott in Support of an Ex Parte Application for Orders to Produce Records Pursuant to Section 11 of the Competition Act and for Sealing Orders, Canadian In re Libor investigation, at 11, (May 18, 2011) ("The Alleged Offences were carried out through e-mails and Bloomberg instant messages ...."). manipulation remains possible. Collusion, which might have left evidence of intent, would have made Libor manipulation far easier. A collusive arrangement of at least five banks would certainly affect the Libor. For example, if the five banks provide "too low" quotes, lower than all other banks, the bottom four will be excluded, but the fifth from the bottom will be included and will manipulate the Libor downwards. If a manipulative cartel forms, as investigators become increasingly convinced occurred, it becomes likely that evidence of their coordination can be found to corroborate intent.

Yet, the levels of collusion required to manipulate Libor are lower than it may seem. Under some circumstances, a single individual can unilaterally affect the Libor rate. ${ }^{135}$ Although outlier quotes are excluded, a bank that moves the included middle of the pack closer to the outer quartile may affect the average, and any bank that arrives in the excluded outer quartile may push in another quote that would have previously been excluded; even banks excluded from the computation of Libor can affect it through false submissions, since it may cause other bank quotes which would not have belonged to the group of eight quotes entering in the Libor computation to be counted. This is the indirect way in which even excluded banks may be able to affect Libor. ${ }^{136}$ Thus, all banks in the panel may unilaterally affect the average by moving the quote in at least one direction. ${ }^{137}$ Collusion would make the scheme much easier, but even smal collusive arrangements could have a meaningful impact for the conspiring parties. Perhaps this is why government investigators have focused on small conspiracies, often a request from a trader at a bank to a colleague working for a voice broker, rather than industry-wide cartels. ${ }^{138}$ When manipulation can occur by the cooperation of just a few individuals within

135. Gabriel Rauterberg \& Andrew Verstein, Index Theory: The Law, Promise and Failure of Financial Indices, 30 YALE J. ON REG. 101 (2013) (explaining how a single bank can manipulate the Libor rate).

136. To make this clear, consider an example with four banks: A, B, C, and D. They submit quotes of $1,2,3$, and 4 , respectively. At the start, $A$ and $D$ are the outlier quotes and excluded. B and C are included and their average is $2 \frac{1}{2}$. At this point, any bank but A can excluded. B and $\mathrm{C}$ are included and their average is $2 \frac{1}{2}$. At this point, any bank but A can
lower the quote. If $\mathrm{B}$ submits $1 / 2$ instead of 2 , then $\mathrm{B}$ is excluded but $\mathrm{A}$ becomes included. The average of $A$ and $C$ is 2 , which is lower than $2 \frac{1}{2}$. If $C$ submits $1 / 2$, then the included set includes $\mathrm{A}$ and $\mathrm{B}$, with average $1 \frac{1}{2}$. If $\mathrm{D}$ submits $1 / 2$ then the included set is $\mathrm{A}$ and $\mathrm{B}$, with average 1 1/2. Only A cannot unilaterally lower the Libor rate. See Rauterberg \& Verstein, supra note 135, at 133-34 (analyzing manipulation mechanics)

137. In fact, fewer than $50 \%$ of the bank quotes are excluded because banks with quotes that tie the middle 50\% are included. Thus, from January 2, 2007 until August 8, 2007, 95\% of panel quotes were included in the average. Rosa M. Abrantes-Metz et al., Libor Manipulation?, 36 J. BANKING \& FIN. 136 (2012). During that period, 95\% of the time, bank could influence the Libor total by changing its quote.

138. See, e.g., Order for the Production of Records, Canadian In re Libor, June 9, 2011 
a bank, the challenge of proving intent through documentary evidence grows.

The challenges in commodities partially parallel those under securities fraud law. In securities litigation, a private plaintiff is required to show the defendant acted with scienter, "a mental state embracing intent to deceive, manipulate, or defraud." 139 Not only is intent required to prove manipulation, but also the threshold for demonstrating intent, even at a motion to dismiss stage, is extremely demanding. As the Supreme Court has put it, "[e]xacting pleading requirements are among the control measures Congress included in the PSLRA [Private Securities Litigation Reform Act]. The [Act] requires plaintiffs to state with particularity ... the facts evidencing scienter, i.e., the defendant's intention...."140 This includes, under the PSLRA, that plaintiffs establish "with particularity facts giving rise to a strong inference that the defendant acted with the required state of mind." ${ }^{\prime 41}$ In Tellabs, the Supreme Court clarified what a strong inference is, stating that " $\mathrm{t}] \mathrm{o}$ qualify as 'strong' within the intendment of $\S 21 \mathrm{D}(\mathrm{b})(2) \ldots$ an inference of scienter must be more than merely plausible or reasonable - it must be cogent and at least as compelling as any opposing inference of nonfraudulent intent." ${ }^{\text {142 }}$ The law thus establishes unusually challenging evidentiary burdens for the demonstration of intent in two primary contexts of financial manipulation: securities and commodities transactions.

\section{Problems of Scope}

Problems of proof are by now familiar. Many profitable manipulations were hard to prove under the CEA, including-if it occurred-Libor manipulation. More importantly, the CEA simply did not purport to cover many transactions that were of great importance. For example, if Libor were manipulated, its greatest impact would be felt in the massive interest rate swap market. Despite frequent efforts by the CFTC to assert jurisdiction, ${ }^{143}$ the Congress amended the CEA to be clear that it did

139. Ernst \& Ernst v. Hochfelder, 425 U.S. 185, 194 (1976); Merrill Lynch, Pierce, Fenner \& Smith, Inc. v. Curran, 456 U.S. 353 (1982) (holding that an implied private cause of action exists under the Commodities Exchange Act).

140. Tellabs, Inc. v. Makor Issues \& Rights, Ltd., 127 S. Ct. 2499, 2504 (2007). See generally Novak v. Kasaks, 216 F.3d 300, 311 (2d Cir. 2000) (analyzing law governing intent in pre-Tellabs, but post-PSLRA era).

141. 15 U.S.C. $\$ 78 \mathrm{u}-4$ (b)(2) (2006)

142. Tellabs, 127 S. Ct. at 2504-05.

143. See Louis Vitale, Comment, Interest Rate Swaps Under the Commodity Exchange Act, 51 CASE W. RES. L. REv. 539, 541-43 (2001) (describing CFTC's efforts to regulate interest rate swaps). not cover Over-the-Counter (OTC) interest rate swaps between sophisticated parties. ${ }^{144}$ In the pre-Dodd-Frank days when much of the sophisticated parties. ${ }^{44}$ In the pre-Dodd-Frank days when much of would not have been eligible for redress under the CEA.

CEA manipulation might still be alleged for exchange-traded derivatives, such as Eurodollar future contracts, but CEA manipulation law was unequipped to remedy such manipulation, even if it were adequately proved. One reason is that the specific intent element is not simply an evidentiary problem of how to show that a defendant intended to create an artificial price. It is a legal standard that actually excuses manipulations where the defendant recklessly created an artificial price while intentionally engaging in some other opprobrious conduct, but did not specifically intend to create the artificial price.

Consider the reputation account of Libor manipulation, in which banks are alleged to have submitted false Libor quotes for no reason other than protecting their reputation. ${ }^{146}$ The quote submitter may not be attempting to injure any particular party. She may not intend to affect the price of a commodity or security. That is a byproduct, barely considered, of her desire to protect the bank's reputation. She may think that her quote will be an outlier from the pack and so excluded from the average and have negligible impact on the Libor rate. Similarly, even if her quote is likely to influence Libor, and so the values of many assets and positions, including those of her firm, she may not have given any thought to the relationship between Libor and those other assets. Her exclusive concern with firm reputation may be reckless, to be sure, but may lack specific intent to cause an artificial price for a swap or commodity.

To go further, the quote submitter may not even know that the quote is false. Libor is quoted in several currencies and tenors per day. In addition to popular tenors like the U.S. Dollar (USD) three-month Libor, it also includes surveys of seven-month Swedish Krona borrowings. Each day the bank is to provide its unsecured rate for borrowing Swedish Krona for seven months in London. Yet the bank may not have borrowed any Swedish Krona in that duration in London that day, ${ }^{147}$ and the BBA rules

44. Commodity Futures Modernization Act of 2000, Pub. L. No. 106-554, § 103, 114 Stat. 2763, 2763A-377-78 (excluding contracts in excluded commodities between eligible contract participants); id. $\S 101$ (adding interest rate to the definition of excluded commodity).

145. Mollenkamp \& Whitehouse, supra note 8.

46. Mollenkaret Fixes Were for Protection, 146. See, e.g., Robert 2912, available at: http://bigstory.ap.org/article/barclays-ceoASSOCIATED PRESS, June 29, 2012, available at: http://bigstory
market-fixes-were-protection (discussing the reputation theory).

market-fixes-were-protection (discussing the reputation theory). 147. The Basics, BBA LIBOR, supra note 100 ("Bbalibor is not necessarily based on
(n) 
disallow the bank to simply take a USD rate and apply a foreign exchange conversion to it. ${ }^{148}$ The BBA asks for data the banks do not really have. The bank must devise some process to answer the question and that proces may be good or bad, forthright or opportunistic, but intentionally false and manipulative would be harder to say. This is not just a problem for obscure currencies.

The most important Libor to swap and loan participants is undoubtedly the three-month Libor. It is the basis of the majority of subprime mortgages, among other assets. ${ }^{149}$ Yet banks borrow very little a the three-month duration any more. Seventy percent of interbank transactions are overnight, and ninety-five percent are for one month or less. ${ }^{150}$ Thus the world's most important benchmark is set from some of the thinnest markets. In the context of thin trading, it is harder for treasurers to report patently false quotes and easier for them to recklessly allow a quote that happens to be helpful to the bank. The problems created by thin markets are not unique to particular currencies or tenors. Suppose a bank gets a cheap loan from the government at a subsidized rate, or a loan from a creditor hoping to protect the borrower's reputation. Should the treasurer include this unusual loan in its assessment of the day's borrowing costs? BBA can help to clarify these issues, ${ }^{151}$ but until it does, there is ambiguity about what counts as the bank's borrowing cost. A treasurer that interprets ambiguity in whichever way benefits her bank may be reckless with the truth, but it is hard to say that there is a specific intent to manipulate.

Even if intentionally misleading quotes were offered with the knowledge that they could affect artificial commodity prices, it is not clear that they would fit under the CEA intention element. The CEA does not require a profit motive for the manipulation. ${ }^{152}$ Nor need the manipulator

the currencies/ maturities they quote and so it would not be feasible to create a full suite of LIBOR rates if this was a requirement.").

148. Definitions, BBA LiBOR, http://www.bbalibor.com/bbalibor-explained/definitions (last visited Jan. 30, 2013).

149. Guhan Venkatu, How Many U.S. Mortgages are Linked to Libor?, FED. RESERVE BANK OF Cleveland (July 10, 2012), http://www.clevelandfed.org/research/trends/2012/0 $712 / 01$ banfin.cfm.

150. Eur. Cent. Bank, Euro Money Market Survey (2007) (noting that seventy percent of transactions are overnight, and ninety-five percent are less than one month).

151. McKenzie, supra note 7; see also author's conversation with John Ewan, Director of BBA Libor (explaining that the unusual loan could be integrated into the submission).

152. See CFTC v. Johnson, 408 F. Supp. 2d 261, 268 (S.D. Tex, 2005) ("We do not agree ... that a 'profit motive' or a 'demonstrated capability of relizing ('We do not necessary elements of a manipulation or an attomption' are omitted). omitted). Note that this would cover even pro-public interest manipulation. Perhaps this is why Hazen includes government and regulatory actions in his chapter on manipulation. JOHNSON \& HAZEN, supra note 12, at 1292-93. even hope to profit at her counterparty's expense. ${ }^{153}$ But it is essential that the defendant have actually intended to manipulate the commodity, rather than trying to manipulate some other item while having reason to know that both prices would be affected. For example, in one case from the Southern District of New York, a plaintiff alleged that manipulations of the Treasury notes market were affecting their positions in Treasury bill and Eurodollar future markets. These markets are intimately related, and it might seem reasonable that if the defendant had intended to manipulate treasury notes, she might have intended also to manipulate Treasury bills and Eurodollar futures. The court found that no claim was stated because Treasury notes were not underlying either Eurodollar futures markets or Treasury bill futures. ${ }^{154}$ It is not difficult to imagine a court finding that if a given bank intended to manipulate Libor, it did not necessarily intend to manipulate Eurodollar futures. The specificity of intent can surprisingly narrow the scope of the CEA.

\section{MANIPULATION AFTER DODD-FRANK: UNFINISHED}

In the aftermath of the largest global financial crisis since the Great Depression, and in the face of ongoing financial scandals discussed earlier in this Article, the CFTC adopted new anti-manipulation rules of potent generality and breadth. In this Part, subpart (A), we overview the new statutory law and regulations and analyze their legal implications. Subpart (B) shows that the new rules may be read as responsive to many of the concerns in Part I. The standards of proof and scope have been adjusted to cover more potential manipulations, including the alleged Libor manipulation. But that does not end the discussion. Subpart (C) shows the changes to CEA manipulation law must be taken to precipitate a change in the technology used in consideration of manipulation. Although it may seem that Dodd-Frank and its implementing regulations reduce the need for complex empirical analysis because it eases the challenge of showing specific intent and artificiality, in fact the legal system must become more attentive to econometric techniques than ever. This is in part because of the factors that Dodd-Frank and the new rules do not address: initial detection, establishing damages causation and recklessness, and pleading standards. Each of these items remains the subject of intense empirical interest, to a degree only highlighted by the new rules. Changing the

153. See Transnor (Bermuda) Ltd. v. BP N. Am. Petrol., 666 F. Supp. 581 (S.D.N.Y. 1987) (stating that defendant oil company alleged to have suppressed the price of oil in order to qualify for favorable UK tax laws).

154. Three Crown Ltd. P'ship v. Caxton Corp., 817 F. Supp. 1033 (S.D.N.Y. 1993). 
elements of the manipulation offense does not by itself end the difficult inquiries that frustrated manipulation before: Complicated factual analyses will still be necessary to detect and plead manipulation, as well as to establish damages. Without empirical support the law will either be toothless or else excessive. Though the new rules address many of the difficulties with the CEA's manipulation regime, the reforms are unfinished if they are implemented through rules alone. They require thorough empirical analysis by courts and parties.

\section{A. Explication of Law}

The authority for the CFTC's new anti-manipulation regulations is section 753 of Dodd-Frank, which amends section 6(c) of the Commodity Exchange Act. ${ }^{155}$ Three amendments and their implementing rules are consequential here. First, section 6(c)(3) extends traditional market power manipulation prohibitions to cover swaps, and clarifies that intent will suffice where the manipulation was unsuccessful: "It shall be unlawful for any person, directly or indirectly, to manipulate or attempt to manipulate the price of any swap, or of any commodity ...."156 Final Rule 180.2 implements the provision: "[I]t shall be unlawful for any person, directly or indirectly, to manipulate or attempt to manipulate the price of any swap, or of any commodity in interstate commerce, or for future delivery on or subject to the rules of any registered entity." "157 The Commission has expressed its intent to continue to be guided by the four-part test for pricemanipulation arising under the previous CEA section 6(c) and CEA section 9(a)(2). As previously explained, based on Russo and extensive case law, the four components are: (1) the accused had the ability to influence market prices and (2) the intent to create or affect prices not reflecting legitimate forces of supply and demand; (3) artificial prices existed and (4) the accused caused such artificial prices. ${ }^{158}$ For attempted manipulation cases, there are only two requisites: the intent and an overt act in furtherance of that intent. Thus, section 6(c)(3) modestly bolsters attempt liability and brings swaps into the market power manipulation regime.

The other two amendments create, for the first time, a fraud-based manipulation scheme under the CEA, and in so doing import vast case law from the federal securities regime. Section 6(c)(1) now declares that: "It shall be unlawful for any person, directly or indirectly, to use or employ, or

155. 7 U.S.C. \$\$ $9,15(2012)$

156. Id. $\$ 9(3)$

157. 17 C.F.R. $\$ 180.1(2012)$

158. Russo, supra note $39, \S 12.11$ attempt to use or employ, in connection with any swap, or a contract of sale of any commodity... any manipulative or deceptive device or contrivance." 159 Section 6(c)(1)(A) extends the scope of section 6(c)'s primary prohibition, including within the reach of unlawful manipulation, delivering "a false or misleading or inaccurate report concerning . . . market information or conditions that affect or tend to affect the price of any commodity... knowing, or acting in reckless disregard of the fact that such report is false, misleading or inaccurate." ${ }^{60}$ In other words, it focuses on manipulation effected through false reporting.

Rule 180.1 implements these amendments. ${ }^{161}$ It prohibits fraud and fraud-based manipulation as well as attempted fraud or manipulation by any person, acting intentionally or recklessly, directly or indirectly, in connection with any swap, cash, or futures contract. Examples of conduct forbidden under rule 180.1 include:

Us[ing] or employ[ing], or attempt[ing] to use or employ, any manipulative device, scheme, or artifice to defraud;

Mak[ing], or attempt[ing] to make, any untrue or misleading statement of a material fact or to omit to state a material fact necessary in order to make the statements made not untrue or misleading;

Engag[ing], or attempt[ing] to engage, in any act, practice, or course of business, which operates or would operate as a fraud or deceit upon any person . .

Knowingly or recklessly] deliver[ing] or caus[ing] to be delivered ... by any means of communication ... a false or misleading or inaccurate report concerning crop or market information or conditions that affect or tend to affect the price of any commodity .... ${ }^{162}$

This new rule differs from pre-Dodd-Frank rules in five important ways. First, it extends to swaps. Second, in contrast with pre-Dodd-Frank cases, in which the Commission had to establish that the fraud was in connection with a swap or cash or futures contract made, or to be made for, on behalf of, or with the victim of the fraud, rule 180.1 contains no similar limitation. Third, while the new law allows trading on nonpublic market information obtained in the usual course of business, material nonpublic market information obtained through fraud or deception or in the breach of a pre-existing duty may not be used unless disclosed. This brings an insider trading rule akin to the securities regime's misappropriation theory

159. Id. $\$ 9(1)$

160. Id. $\S 9(1)(\mathrm{A})$

161. 17 C.F.R. $\$ 180.1$ (2012).

162. Id. 
to commodities and swaps.

Fourth, rule 180.1 relaxes two key elements of manipulation claims: artificiality and intention. It expands the scienter standard to include reckless behavior, which may be sufficient by itself without the specific intent to defraud or manipulate.

Finally, it is evident from the statutory language (and the language of the final regulations themselves), that the anti-manipulation rules import the language, and hence, presumably the case law of securities fraud under section 10(b) of the Securities Exchange Act of 1934 (SEA) and SEC Rule 10b-5, codified at 17 C.F.R. $§ 240.10 b-5 .{ }^{163}$ The legal implications of the 180.1 anti-manipulation rules are vast, and it is clear from the language and scope of the regulations that their drafters intended to have the kind of impact on the trading of commodities that Rule 10b-5 has had on the securities markets. ${ }^{164}$

It may even go further: Section 6(c) encompasses attempt, unlike section $10 \mathrm{~b}$ of the SEA, and lacks Rule 10b-5's requirement of a purchase or sale. The implications of these rules are enormous, but our focus is on their interaction with cases of complex potential financial manipulation. Depending on the species of manipulation, sections 180.1(a)(1), (2), (4) and section 180.2 are all pertinent.

\section{B. Application to In re Libor}

The new provisions seem responsive to some of the challenges for pre-Dodd-Frank manipulation law, and so provide a means to address alleged Libor manipulation. With rule 180.2, CFTC intends to extend its four-element price manipulation standard into this new rule, subjecting swaps for the first time to this liability scheme. ${ }^{165}$ Much of the Libordependent market includes exchange-traded and OTC swaps. The new rules clearly bring these into the fold.

Rule 180.2 also covers attempted manipulations. This may prove essential to covering cases where the manipulation was ineffective, and so did not create an artificial price. For an example from the alleged Libor

163. Comments of Daniel Arthur, Romkaew P. Broehm, \& Gary Taylor regarding Proposed Rules 17 C.F.R. $\$ 180.1$ and 180.2, at 2, http://www.brattle.com/_documents/Uplo adLibrary/Upload905.pdf.

164. See Prohibition on the Employment, or Attempted Employment, of Manipulative and Deceptive Devices, 76 Fed. Reg. 41,398, 41,410 (July 14, 2011) (statement of Chairman Gary Gensler) ("This rule implements new Dodd-Frank authorities to police against fraud and fraud-based manipulative schemes, based upon similar authority that the Securities and Exchange Commission, Federal Energy Regulatory Commission and Federal Trade Commission have for securities and certain energy commodities.").

165. Id. at $41,407-08$ manipulation, a bank that is already in the excluded quartile might submit a fo excluded quartile in an attempt to false quote that is even further into the excluded quartile in an attempt to influence the Libor rate. This attempt would be unsuccessful since the rate would not change as a result of this quote. However, the activity is the type of conduct that many would agree should be proscribed. The attempt prong may be essential to prosecuting a panel bank whose quotes fall outside the mean-shaping quotes for the critical period and thus, arguably, is not part mean-shaping quotes for the critical period and thus, arguabry of the eight quotes that shape the mean and generate Libor's value. The rules also specifically contemplate attempt liability for an employee who re make a fraudulent misstatement, but has that order orders a subordinate to make a robust internal controls.

The Commission's authority is extended with respect to pre-Dodd Frank rules through its prohibition of manipulation and attempted manipulation that is either direct or indirect. It expects to exercise its manipulation that is either direct or indion to affect cash authority "where the fraud or manipulation has the polential to affect cash commodity futures, or swaps markets or participants in these markets.

Rule 180.1 creates new types of mection 180.1 different standards. The key inclusion of "recklessly" in the section 180.1 definition of scienter is thought to substantially ease the specific intent requirement. The Commission defines recklessness as "an act or omission that 'departs so far from the standards of ordinary care that it is very difficult to believe the actor was not aware of what he or she was doing."”168

This certainly eases the burden of proving manipulation. Although intent can be proved by external evidence, it is a subjective state. On the intent can be proved by cxternal enduct that other hand, recklessness is fucto have had requires judgments about what information an actor should have had and what results she should have anticipated, regardless of whe acquired that information or intended any particular result.

More interestingly, a recklessness standard seems to capture many of the hitherto elusive manipulations that might have occurred in the Libor disruption. For example, the reputation theory has it that Libor is manipulated as an indirect result of the direct and specific desire to provide manipulated as an intificial prices in a submission quote that protects the banks' reputation. Artificial prices in loans, swaps, and Eurodollar futures are a more indirect result still. It is not
clear that a trader who did not think at all about those results would have had the specific intent requirement for CEA manipulation under the pre-

166. Id. at 41,403

67. Id. at 41,401 (emphasis added).

168. Id. at 41,404 (quoting Drexel Burnham Lambert Inc. v. CFTC, 850 F.2d 742, 748 (D.C. Cir. 1988)) 
Dodd-Frank rules. Now, it is clear that she would be eligible for reckless liability. Even if she did not want or know about those other price effects, it is very difficult to believe that she was not aware of what she was doing, and of course she departed far from an ordinary standard of care.

Recall also that many tenors of Libor are thinly traded and so provide the bank officer little evidence either way on what the appropriate Libor quote should be. Here, it is hard to establish specific manipulative inten because the officer can hardly be said to have offered a quote that she knows to be false. If there were no loans at all made at that tenor, and there have been none in a while, how can a particular number be assuredly incorrect? Rather, she is simply being reckless by offering a quote that she has no good reason to think true, and it would seem to fall below a standard of ordinary care to give a quote that is not the fruit of a diligent information-gathering process. Similarly, suppose a bank determined that it would use a different methodology every day to determine its Libor quote, selecting whichever yields the lowest quote. It is unlikely that this calculation method amounts to a specific intentional manipulation as such, but it probably yields reckless quotes.

The new rules also bring CEA enforcement to areas of overlap between the Commodities Exchange Act, the Securities Exchange Act, and Antitrust laws. Many times, violations of the CEA are also violations of the SEA or of the Sherman Act. For example, security-based swaps are under the jurisdiction of both the SEC and the CFTC. Similarly, some manipulative or fraudulent schemes may cover a variety of security and commodity assets. Some defendants may already be liable under the SEA Yet allowing claims under the CEA that parallel the SEA is not mere superfluity because the CEA authorizes a wider range of defendants than does the SEA.

In Central Bank of Denver, N.A., v. First Interstate Bank of Denver, N.A. ${ }^{169}$ the Supreme Court limited liability under section 10(b) of the SEA and rule 10b-5 to only "primary" perpetrators of fraud. ${ }^{170}$ The Court ruled that there is no private right of action against secondary actors such as lawyers, investment bankers, and accountants who may have facilitated the fraud but did not personally make a false or misleading claim. ${ }^{171}$ Subsequent decisions have only confirmed the SEA's focus on primary actors. ${ }^{172}$ By contrast, the CEA explicitly grants a private right of action

\footnotetext{
169. 511 U.S. 164 (1994)

170. Id. at 191.

171. Id.

171. See Stoneridge Inv. Partners, LLC v. Scientific-Atlanta, Inc., 552 U.S. 148,158 (2008) (limiting "scheme" liability for secondary actors who have not made a false or
} misleading public statement or otherwise obtained a duty to disclose); see also James C. against secondary actors. ${ }^{173}$ Thus, where an activity violates both the SEA and the CEA, such as a fraud that concerned both swaps and securities or of security-based-swaps where the CFTC and SEC have overlapping jurisdiction, secondary actors who are not liable under the SEA may still be subject to suit under the CEA. The arrival of CEA manipulation to the realm of swaps and security-based swaps increases the degree of vicarious liability.

With rules implementing Dodd-Frank's anti-manipulation provisions, the U.S. is now a leader in both civil and criminal enforcement capacity for manipulation of financial indices and benchmarks, with regulators around the world taking the Libor disruption as an opportunity to decide whether they too should implement rules akin to Dodd-Frank's. ${ }^{174}$

\section{The Dangers of Dodd-Frank: Market Manipulation and} Intervention

It may seem that these new regulations solve problems and reduce the need for expert economic analysis in adjudication. Yet, they require empirical support to strengthen and temper their potential.

The other side of powerful rules is the dangers of overdeterrence and mistargeted prosecution. Rule 180.1 suits predicated on recklessness allow plaintiffs to avoid the marked difficulties of demonstrating intent or artificiality. The downside of this elimination, however, is that recklessness opens the door to the prosecution of innocent (though complicated) economic behavior. This is particularly important at the pleading stage, where it may appear that vastly more plaintiffs will be able to survive a motion for summary judgment even where their claims are baseless. The new rules underline the importance of well-employed

Dugan \& Todd G. Cosenza, The Future of Secondary Actor Liability Under Rule 10(b)-5 Affer Stoneridge Investment Partners, LLC v. Scientific-Atlanta, Inc., 5 N.Y. U. J. L. \& Bus. 793, 793 (2009) ("']"]t was widely believed that [Stoneridge] limited the ability of securities

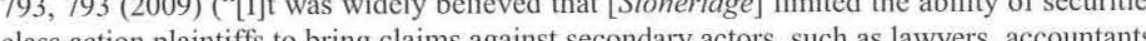
, and investment bankers, who did not themselves make any false or misleading statements.").

173. 7 U.S.C. $\$ 25(a)(1)$ (2012) ("Any person (other than a registered entity or registered futures association) who violates this chapter or who willfully aids, abets, counsels, induces, or procures the commission of a violation of this chapter shall be liable for actual damages .....") (emphasis added).

174. See WHEATIEY REVIEW, supra note 117, at 11 (urging greater enforcement powers for FSA); Gary Gensler, Chairman, U.S. Commodity Futures Trading Comm'n, Transcript for FSA); Gay Gens Ber Brussels Belgium (Sept. 24, 2012), available at http://Www.cfc.gon/acn/groups/public/@n ewsroom/documents/speechandtestimony/opagensler-121.pdf (urging provisions similar to U.S. enforcement authority). 
economic analyses as an essential boundary to the new rules. ${ }^{175}$ If economic tools can act as a buffer against the new rules, filtering out claims that implicate benign but complex swap transactions, it can lower the costs and reduce the fears of law-abiding swap market participants.

\section{PROPOSAL: ECONOMETRIC SCREENS}

The new rules establish lower burdens in manipulation trials, while not altering the actual difficulty of detecting manipulation, the difficulties of proving causation and damages, or the importance of crafting an appropriate pleading standard. This section describes some of the issues left unanswered by the new law, and alludes to the econometric technologies that are needed to supplement the new law. It describes screening methodologies for detecting, proving, and dismissing alleged manipulation. We describe examples of these three uses based on the professional experiences of one of the authors.

\section{A. Screens for Detection}

Regardless of how Dodd-Frank and its implemented rules adjusted the elements of manipulation, no claims will be brought if manipulation is not itself detected. The art of flagging potential unlawful behavior through economic and statistical analyses is commonly known as screening. ${ }^{176} \mathrm{~A}$ screen is a statistical test based on an econometric model and a theory of the alleged illegal behavior, designed to identify whether manipulation, collusion, fraud or cheating of any kind may exist in a particular market. Screens use commonly available data such as prices, bids, quotes, spreads,

175. See Robert S. Bloink, Does the Dodd-Frank Wall Street Reform Act Rein In Credit Default Swaps? An EU Comparative Analysis, 89 NeB. L. Rev, 587, 608-12 (2011) (questioning whether Dodd-Fank's reforms went for enough in managing the risks (questioning whether

176. For surveys of screening methodologies, their multiple applications, and how to properly develop and implement a screen, see Rosa Abrantes-Metz, Libor Litigation and the Role of Screening: The Need for Enhanced Compliance Programs, COMPETITION POL'Y INT'L ANTITRUST Chron., July 2011 [hereinafter Abrantes-Metz, Role of Screening]; Rosa Abrantes-Metz \& Patrick Bajari, Screens for Conspiracies and their Multiple Applications, 24 AnTITRUST 66 (2009) [hereinafter Abrantes-Metz \& Bajari, Screens for Conspiracies]; Rosa Abrantes-Metz \& Patrick Bajari, Screens for Conspiracies and Their Multiple Applications Extended, 6 COMPETITION POL'Y INT'L 129 (2010) [hereinafter Abrantes-Metz

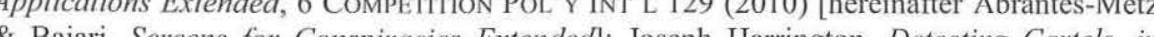

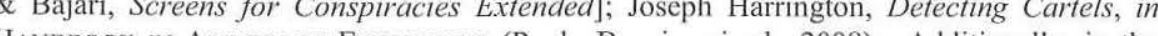
HANDBOOK IN ANITRUsT LeONOMics (Paolo Buecirossi ed., 2008). Additionally, in the context of detecting conspiracies, screens can be successfully used as detailed in A.B.A. Section of Antitrust Law, Proof of Conspiracy under Federal Antitrust Laws, ch. VIII (2010). market shares, or volumes to identify patterns that are anomalous or highly improbable.

Broadly speaking, the literature identifies two primary screening strategies. The first is to search for improbable events. This type of screen is similar to looking for a "cheat" in a casino. For example, the probability that a gambler at a Las Vegas casino will place a winning bet in roulette on black or red is $47.37 \%$. During a shift, a roulette dealer may see a handful of players win five, or even seven, times in a row. However, the probability of winning twenty times in a row is around one in a million. If a pit boss observes such an occurrence, he may not be able to prove that cheating has occurred, yet he would be well advised to watch the winner closely to avoid the risk of losing a significant amount of money. One set of collusive screens generalizes this idea by searching for events that are, under normal conditions, improbable, unless agents in a market are cheating.

The second type of screen uses a control group. As an example, during the $1980 \mathrm{~s}$, one study found that the price of concrete was seventy percent higher in New York City than in other U.S. cities. While it is true that the prices of many goods and services are somewhat higher in New York City, relatively few of those prices are seventy percent higher than in other large cities. It was later established that an organized crime syndicate in New York City had been operating a concrete club that rigged bids on in New markets, suggest a lack of competition.

This section continues by describing (1) the use of screens in government investigations, and (2) the use of screens in detecting anomalies in Libor data.

\section{Government Detection}

Antitrust law has long been receptive to economic analyses, both in terms of governmental regulation and judicial decision-making. This section seeks to give a quick recapitulation of these features in order to illuminate how commodities manipulation could similarly benefit. To begin with, seminal Supreme Court decisions have often cited economics literature as support for the directions that antitrust law takes. ${ }^{177}$ Indeed, the Supreme Court has warned against not conferring evidentiary weight on

177. See, e.g., Brooke Grp. Ltd. v. Brown \& Williamson Tobacco Corp., 509 U.S. 209, 233 (1993) (citing economic analyses as support for claim that "[s]upracompetitive pricing entails a restriction in output"). 
sound economic analyses. ${ }^{178}$

Economic analysis and empirical screening have had great success in triggering antitrust cases, including actions against an Italian cartel in the baby milk industry and a Dutch cartel in the shrimp industry. Screens have also been used successfully to identify potential anti-competitive behavior in gasoline markets by the Federal Trade Commission, and to prioritize complaints in the Brazilian gasoline retail market, leading to raids and the discovery of dispositive evidence. ${ }^{179}$ In Mexico, the competition authority has initially flagged a conspiracy in pharmaceutical markets through the use of bid-rigging screens, while in India screens were applied to detect a cement cartel. ${ }^{180}$ Competition authorities worldwide are using empirical screens to detect anti-competitive behavior, including the FTC, the European Commission, and competition authorities in The Netherlands, Austria, Italy, Turkey, Hungary, Brazil, Mexico, India, and South Africa. ${ }^{181}$

Two different examples can illustrate the power of screens to detect anti-competitive behavior in financial markets. One is the recent stock options backdating and spring loading cases from the mid-2000's and the other is the 1994 break of an alleged conspiracy by NASDAQ dealers in which odd-eighths quotes were avoided. ${ }^{182}$ Both of these were triggered by the application of screens to financial data and generated large size investigations as well as private litigation.

178. See Brown Shoe Co. v. United States, 370 U.S. 294, 329 (1962) (explaining that "[i]n such cases, it becomes necessary to undertake an examination of various economic and historical factors in order to determine whether the arrangement under review is of the type Congress sought to proscribe").

179. M.R. Venkatesh, Of Cement, Cartels and Corruption, REDIFF INDIA ABroAd (Jan. 179. M.R. Venkatesh, Of Cement, Cartels and Corruption,
17, 2008), http://www.rediff.com/money/2008/jan/17cartel.htm.

180. Org. for Econ. Co-Operation and Dev., Fighting Bid Rigging in Public Procurement IN MEXICo (2011), available at http://www.oecd.org/daf/competition/abuseof dominanceandmonopolisation/49390114.pdf.

181. Rosa M. Abrantes-Metz, Screens for Conspiracies and their Multiple Applications, (A.B.A. Brown Bag Series "Beyond Leniency: Empirical Methods of Cartel Detection"), Dec. 15, 2011, http://www.americanbar.org/content/dam/aba/publications/antitrust law/2 0111215 at 1215 materials.authcheckdam.pdf; Abrantes-Metz \& Bajari, Screens for Conspiracies Extended, supra note 176; Abrantes-Metz et al., supra note 119. It is also increasingly important and recognized to be important that derivatives regulators cooperate internationally. See, e.g., Brooksley Born, International Regulatory Responses to Derivative Crises: The Role of the U.S. Commodity Futures Trading Commission, 21 Nw. J. INT'L. L. \& BUS. 607, 609-10 (2001) ("Recognizing that 'derivatives markets serving United States industry are increasingly global in scope' and that 'events that disrupt financia markets and ceconomies are often global in scope, require rapid regulatory response, and latory effort across international juris that the CFTC should 'continue to coordinate with foreign regulatory authorities, to participate in international regulatory organizations and forums ...."”)

182. Rosa Abrantes-Metz, The Power of Screens to Trigger Investigations, 7:10 SEC LiTiG. ReP. 17 (2010).
The CFTC monitors trading and prices to screen for candidates that may warrant a closer look to detect potential illegal behavior. The Commission's monitoring and screening program uses several sources of market information. Some data are publicly available, such as data on overall supply, demand, and marketing of the underlying commodity; also futures, options and cash prices, and trading volume. Other information may be highly confidential, and that includes data from exchanges, intermediaries, and large traders. As exchanges report daily positions and transactions of each clearing member to the Commission, those data may be analyzed as part of the screening effort. The data separately show proprietary and customer accounts and the aggregate position and trading volume of each clearing member in each futures and option contract. These can be used to quickly identify the firms clearing the largest buy or sell volumes or holding the biggest positions in a particular market, though beneficial owners of the positions are not identifiable in these clearing data. As explained by the CFTC:

[The] market surveillance program is intended to preserve the economic functions of U.S. futures and option markets under its jurisdiction by monitoring trading activity:

- to detect and prevent manipulation or abusive practices,

- to keep the Commission informed of significant market developments,

- to enforce Commission and exchange speculative position limits, and

- to ensure compliance with Commission reporting requirements.

The market surveillance program's primary mission is to identify situations that could pose a threat of manipulation and to initiate appropriate preventive actions. Each day, for all active futures and option contract markets, the CFTC's market surveillance staff monitors the daily activities of large traders, key price staff monitors the daily activities of large traders, key price continuous review for potential market problems. ${ }^{183}$

Price aberrations in the cash market for an underlying financial instrument may provide an opportunity for an attempted manipulation. CFTC staff monitors cash prices of the financial instrument specified for delivery on the futures contract in relation to cash prices for nondeliverable instruments that are close, or identical substitutes, noting that when deliverable prices are high relative to non-deliverable prices for

183. CFTC Market Surveillance Program, U.S. COMmodity Futures TRADING Cомm'N, http://www.cftc.gov/IndustryOversight/MarketSurveillance/CFTCMarketSurveilla nceProgram/index.htm (last visited Jan. 30, 2013) 
financial instruments, it may flag the possibility to remove deliverable supplies from the futures market as part of an attempted manipulation. ${ }^{184}$ Additionally, the Commission explains that another flag for manipulative activity is when market participants take positions well beyond their financial capacity to take delivery or make settlement. The CFTC explains that it maintains open lines of communication with the Treasury Department, the Federal Reserve Bank of New York, the SEC and other agencies, since several financial products involve US Treasury or agency instruments (e.g., bonds or notes).

With respect to cash-settled markets, the CFTC explains that its focus is on the integrity of the cash price series used to settle the futures contract. The size of a trader's position at the expiration of a cash-settled futures contract cannot affect the price of that contract because the trader cannot demand or make delivery of the underlying commodity. Since manipulation of the cash market can yield a profit in the futures contract, the CFTC monitors large reportable futures positions and is alert for unusual cash market activity on the part of large futures traders, which is particularly important during the time in which final cash price for futures settlement is determined.

\section{Non-Government Detection}

It is not only governments that can use screens to detect manipulation. This section describes a recent use of screens by one of co-authors of this piece and two other scholars (Abrantes-Metz, Kraten, Metz and Seow (2008)), which flagged a possible conspiracy and manipulation of the U.S. Dollar London Interbank Offered Rate ("Libor"). ${ }^{185}$ The results of this study, and preliminary evidence previously put forward by the Wall Street Journal, warranted a closer look at the data. Presently, government regulators, ${ }^{186}$ scholars, ${ }^{187}$ trade associations, ${ }^{188}$ and private litigants ${ }^{189}$ have

184. Id.

185. Abrantes-Metz et al., supra note 137.

186. See, e.g., Joseph Palazzolo, Jean Eaglesham \& Carrick Mollenkamp, U.S. Asks if Banks Colluded on Libor, WALL ST. J., Apr. 14, 2011, at C1 (stating that "U.S. investigators are examining whether some of the world's biggest banks colluded to manipulate a key interest rate before and during the financial crisis, affecting trillions of dollars in loans and derivatives...."); see also Donald Griffin, Citi Penalty Sought in Japanese Tibor Probe, BLOOMBERG, Dec. 8, 2011, available at http:/www businessweek com/news/2011-12

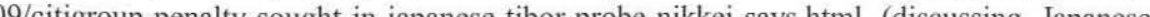

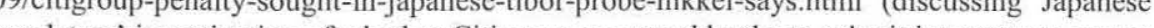
regulators investigation of whether Citigroup pressured banks to submit interest rate quotes to manipulate the Japanese index interest rate in its favor); Brooke Masters, Patrick Jenkins \& Justin Baer, Big Banks Investigated Over Libor, Fin. Times, Mar, 15, 2011 (last updated Mar. 15, 2011, 10:24 PM), http://www.ft.com/cms/s/0/ab563882-4f08-11e0-9c25- all developed a keen interest in understanding whether Libor acted atypically during the crisis, and whether, if it did, this was the result of human manipulation. Initial interest in the potential manipulation of Libor is the result of screen application. Not only did this screen help to raise initial concerns as to Libor disruption; it also directed subsequent inquiries as to which periods of time most warrant additional scrutiny.

The design of the study was as follows: Abrantes-Metz and colleagues compared the one month Libor and the four month Libor-the rate at which large London banks purport to be able to borrow on an unsecured basis for one and three months at a time - to the Federal Funds Effective rates. The authors present the results for the one-month Libor and explain that they are qualitatively identical for the three-month Libor. These rates should not be identical. The Federal Funds Effective rate represents overnight loans from one depository institution to another. However, given the short-term, unsecured nature of the loans, it would be intuitive for them to exhibit some relationship. Similarly, when AbrantesMetz and her colleages compare Libor to the one-month Treasury rate, it would be unsurprising if some historic relationship existed. Libor may be a higher rate than the Treasury rate because it exposes lenders to the risk of a bank's default rather than that of the United States itself, presumably a higher risk ${ }^{190}$ but both include the cost of borrowing money. For them to wildly diverge for no reason would be cause for some subsequent inquiry.

Abrantes-Metz and her colleagues determined the typical spread between Libor and these other rates going back to 1990 and then compared it to the spreads during recent months. The Figure below, extracted from Abrantes-Metz, Kraten, Metz and Seow (2008), represents the one month U.S. dollar Libor from January 2007 through May 2008, plotted against two comparable rates, the Federal Funds Effective rate and the one month Treasury-bill.

00144feab49a.html\#axzz2JVE4kS00.

187. Snider \& Youle, supra note 112; Jacob Gyntelberg \& Philip Wooldridge, Interbank Rar. Fin Rate Fings Dining Recor

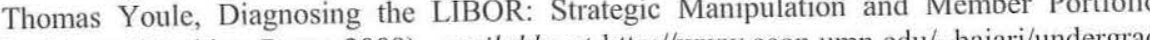
Positions (Working Paper 2009), available at http://www/econ iosp10/LiborManipulation.pdf.

188. Press Release, Ass'n of Corp. Treasurers, supra note 120. But see ACT Stresses the Importance of LIBOR and EURIBOR to Companies, ASS'N OF CORP. TREASURERS, http://www.treasurers.org/node/7329 (last visited Jan. 30, 2013) (showing appreciation for LIBOR and EURIBOR).

189. See Rauterberg \& Verstein, supra note 135 , at *58 (analyzing litigation claims).

190. But see, e.g., Richard Wolff, O\&A: What If U.S. Defaults on Debt? 190. But see, e.g., Rich July 15,2011, 1.37 PM), htp://usatoday 30 usatoday com/

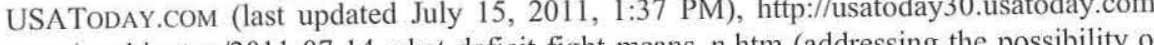
news/washington/2011-07-14-what-deficit-fight-means_n.htm (addressing the possibility of the United States defaulting on its debt in the wake of the 2011 debt ceiling crisis) 
FIGURE 1

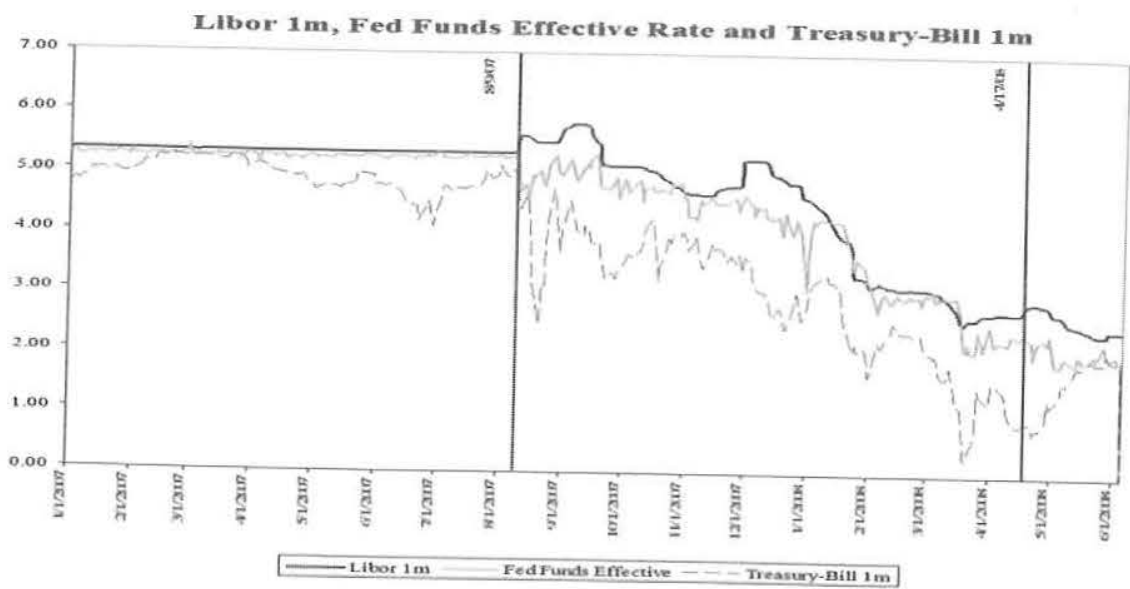

(Abrantes-Metz, Kraten, Metz and Seow (2008 \& 2012))

Several interesting observations can be made from this graph and the associated data. First, the Libor rate seems to move through distinct phases between the start of 2007 and the middle of 2008. Superficially, the Libor rate appears to be essentially constant for the first 8 months of 2007 before it begins to fluctuate rapidly. Abrantes-Metz and her colleagues find the Libor quotes during that period suspicious. They also confirmed a suspicious breakdown between banks' individual Libor quotes and their own CDS spreads. Banks that reported lower borrowing costs than their peers in terms of their Libor (implying relative stability) were often more expensive to insure in the CDS market (implying a lack of stability). ${ }^{191}$ Other empirical studies followed by Snider and Youle ${ }^{192}$ and AbrantesMetz and her colleagues. ${ }^{193}$ These studies employ additional screens to flag certain anomalous patterns in the Libor data.

191. Rosa M. Abrantes-Metz et al., Libor Manipulation?, 36 J. BANKING \& FIN. 136, 147 (2012).

192. Snider \& Youle, supra note 187; Snider \& Youle, supra note 112

193. Abrantes-Metz et al., supra note 119. In many data sets, the distribution of digits has a natural, regularly occurring pattern. Benford's Law is a mathematical for of digits describes this distribution. Studies have shown that the law applies to a surprisinula that number of data sets, and violations can raise questions as to whether the daringly large manipulated or artificially vene been manipulated or artificially generated. Benford's Law is commonly applied in accounting
applications to screen for manipulated or falsified financial statements.
While the research studies cited above generally acknowledge anomalies in the Libor quote data, they are merely suggestive of wrongdoing. In fact, the 2008 study by Abrantes-Metz and her colleagues specifically benchmarks the Libor against other contemporaneous shortterm, risk-free rates in periods not suspected of manipulation, applies those benchmarks to the suspect periods, and finds that the average level of the Libor does not deviate in a statistically significantly manner from these benchmarks. Yet screens like this have helped trigger investigations that will look for other evidence for or against the suspicious behavior. Ultimately, very profitable manipulations could have happened within the margin of error, making even low certainty results warrant further investigation. The Libor litigation will provide a fruitful example of the multiple uses of screens, and it has already shown how powerful these can be in identifying situations warranting a closer look.

While the CFTC maintains extensive monitoring systems, journalists and economists flagged the Libor disruption. There is no reason for screening tools to be isolated to the government, and Libor shows the great fruits of non-governmental screen use. There are many uses of screens for market participants. It is critical for market players to know and anticipate how they may be screened. For potential plaintiffs, screening techniques may help them to note potential manipulation at all, the first step in redressing it. Potential defendants would do well to establish screening within their governance and compliance programs. Insofar as firms do not wish to be the targets of investigations and lawsuits, they will attempt to prevent their own staff from engaging in manipulative actions that can be imputed to the firm. Screens can be a crucial tool in helping firms locate and stop problems within their own house, rather than in a court later. It is far better to hear about and remedy manipulation detected through an inhouse screen than after a conversation with regulators.

Any of the individual banks providing Libor quotes could have (and some of them might have) used such methods themselves to identify the same anomalies in real time. An internal audit or compliance function, by anticipating these regulatory investigations, could have protected the banks against allegations of malfeasance, or at least could have been an important factor in convincing authorities that significant efforts had been made by the company to detect any possible wrongdoing, if any did exist. They could also have been used by the agencies themselves to flag the possibility of wrongdoing.

\section{B. Screens in Proof}

Although recklessness will now suffice rather than intentional 
artificiality, econometric proof has not been reduced in importance for adjudication. Artificiality may not be an element in 180.1 actions, but scale of price distortion may be an important factor in computing damages, as will causation. ${ }^{194}$ Screens can be a useful tool in establishing damages and causation, and as well as pressing a 180.2 claim with respect to swaps. For obvious reasons, any empirical approach to present or defend allegations of fraud and manipulation relies not only on the actual facts of the case, but also on the type of direct evidence available. For example, a 180.1 action could be brought in part based on emails between traders that seem to indicate the use of a fraudulent device. But trader-speak can often be ambiguous, and supporting economic evidence may help prove or disprove that their communications indicated fraud.

Economic analyses in general, and screens and other types of empirical approaches in particular, can play critical roles in these circumstances. Scholars have been calling for increased attention to economic analyses for some time. ${ }^{195}$ The success of screens in focusing attention on Libor and the new CFTC rules simply offer the most opportune moment yet for commodities manipulation law to move forward.

The role of economic analysis and the economic expert can be very important in inferring intent under these circumstances by performing a variety of studies on what is "usual" market and trading behavior and what may be considered "unusual" and potentially indicative of manipulation.

This section presents possible empirical analyses for hypothetical situations that may be undertaken for particular types of cases

1. Possible Empirical Analyses for a Hypothetical Case Brought Under Rule 180.1

Imagine that the CFTC has brought allegations of conspiracy and manipulation against traders in a financial services firm called Gospis and brokers in a brokerage firm called Brokatus. Specifically, the CFTC alleges that some brokers from Brokatus conspired to obtain new business and increase existing business in swaps as well as in cash and futures transactions from Gospis' traders. This group of brokers (call it "allegedly tainted brokers") provided a variety of gifts to the aforementioned group of traders (call it "allegedly tainted traders"), a practice that was not allowed

194. Commodity Exchange Act $\$ 6(c)(10)(C)$ (ii) (codified as amended at 7 U.S.C. \$ 9(10)(c)(ii)) (allowing treble damages).

195. See, e.g., Pirrong, supra note 17, at 63 (prescribing that "the amended law should explicitly prescribe, endorse, or recommend the use of statistical and econometric methods to establish the existence of specific anomalous price and quantity relations" in order to enhance the efficiency of U.S. future market anti-manipulation regulation). by either Brokatus or Gospis. The CFTC also put forward the theory that the allegedly tainted brokers were of lower quality when compared to the other brokers at Brokatus, which was the reason why they had to bribe traders at Gospis.

An economic expert employed by one of the parties will undertake a variety of analyses to determine whether there is any empirical support for these allegations. There are fundamentally two inquiries to pursue. First, was there a causal relationship between gifts and trade execution quality. Second, was there an incentive for the tainted traders to actually select their brokers based primarily on the gifts received.

On the first point of execution quality, one approach is to compare the quality of execution of the pairs of allegedly tainted traders and brokers during the allegation period against appropriately untainted benchmarks. The quality of execution could be measured by the amount by which those trades beat average market prices, thus producing benefits for Gospis. If gifts were the reason why the tainted traders chose to place their trades with the tainted brokers, then we should expect to observe a lower quality of execution between these pairs and any other untainted pairs. There are several untainted benchmarks to be considered: (i) the same pairs of allegedly tainted traders and brokers before the allegation period; (ii) the same allegedly tainted traders when placing their trades with untainted brokers during the allegation period; (iii) untainted traders when placing the orders with allegedly tainted brokers during the allegation period; and (iv) untainted traders when placing their trades with untainted brokers.

The economic expert will search for lower execution quality for the pairs of allegedly tainted traders with allegedly tainted brokers during the allegation period, when compared to any of the four benchmarks above. Changes in the relationships between allegedly tainted traders with allegedly tainted brokers from before the allegation period to during the allegation period would also be considered, and compared to changes during the same periods of time between any of the benchmark groups.

Just as important as the choice of the benchmarks is the specification of the model explaining quality of execution. It is important to frame the analysis in the context of a multiple regression model so that a variety of potentially relevant factors can be taken into consideration, and a measure of materiality can be scientifically obtained through statistical significance. Such factors to take into account are: the characteristics of the contracts and swaps involved; the trading conditions on a daily basis (for example, if there was any relevant news on those days); the time of the transaction (was it in the last few minutes before floor trading closed for the day), or time to floor trading close; market depth; market liquidity; floor versus electronic trading; market volume for the day and during the last few 
minutes of floor trading when applicable; relative size of the trade in terms of volume for the relevant time period; number of transactions in the last few minutes; times when brokers received traders' orders and execution times of those trades; relevant sectors; specific transaction orders (as for example, if the broker can break a large trade into several blocks or not) and order types; portfolio manager instructions; multi-broker placements; relevant price average values and volatility; recent relevant prices trends; basis value when applicable (measured as the futures minus the spot/cash price); residual interfund trades; number of other trades placed in the same few minutes interval; day of the week; and potentially other factors.

With the results of these models, a variety of tests can be run in order to establish any material differences in execution quality for the pairs of allegedly tainted traders and brokers during the allegation period, when compared to benchmarks.

Are the qualities of execution from the allegedly tainted pairs statistically different from, in particular lower than, the qualities of execution for any of the other benchmark pairs?

After taking into account all of the factors that may explain quality of execution as outlined above, let's consider the regression errors as containing all other explanations for execution quality that were not directly controlled for in our model. Do these regression errors differ in terms of variances, and overall distributions, between the allegedly tainted pairs and any of the benchmarks?

Does the execution quality of allegedly tainted pairs present the same variability over time as those from benchmarks?

How do the trades from these pairs of allegedly tainted traders and brokers compare to the overall universe of trades between all traders and al brokers? Do they tend to be on the lower end of the distribution?

Are there either a larger number of negative qualities of execution for the allegedly tainted trader and broker pairs, or more significant negative values, when compared to the benchmarks?

Suppose there are 30 such pairs of allegedly tainted traders and brokers, and that there is a universe of 450 pairs of traders and brokers that are untainted (benchmarks (i)-(iv)). If we draw 10 random samples of qualities of execution from the 450 untainted pairs of size 30 pairs each, how do these compare to the qualities of execution of the 30 allegedly tainted pairs? Can we distinguish the 30 allegedly tainted pairs against any of the other random samples of the same size, in terms of any of the relevant features of the quality of execution?

The same analyses that are carried out for the group of tainted traders and brokers over time would also be undertaken at a more micro level, such as the ones outlined below.
On a daily basis, how does the intraday variability of the qualities of execution for the allegedly tainted traders and brokers compare to the intraday volatility for the remaining benchmarks?

Are there a larger proportion of negative qualities of execution for the allegedly tainted pairs than for the benchmarks on a daily basis? Are the negative values for the qualities of execution of the allegedly tainted pairs larger in terms of magnitude than those of the untainted pairs, again on a daily basis?

Amongst all of the 30 allegedly tainted pairs during the allegation period, can we identify any particular pairs which seem more suspicious in terms of the characteristics of the quality of execution, meaning that performed worse in terms of quality of execution?

Amongst all of the 30 allegedly tainted pairs, what was the proportion that performed better than the average of all trades, the same, and worse than the average of all trades? How do these proportions compare to the same proportions across all of the untainted pairs? And how do these proportions compare with respect to those in 10 random samples of size 30 untainted pairs each?

Of course, other more specific analyses may also be undertaken by defendants' economic expert and the CFTC, but for the most part, their core would be similar to those outlined above.

With respect to the second point on the incentive of traders to select brokers based primarily on gifts received, these traders had strong financial incentives to perform well. Traders had the incentive to choose the "right" brokers so that their compensation could be maximized. Traders' compensation was based on their financial performance, which is a function of a volume-weighted price metric for all of their transactions, and also of the classification of the traders' work by their respective portfolio managers.

Hence, a starting analysis on the incentive question would compare the quarterly compensations for the allegedly tainted pairs of traders and brokers against the compensations of the same benchmarks in (i)-(iv) factoring in other relevant and determining factors. The analysis would pose similar questions about the compensations of these allegedly tainted pairs as those in (1) through (9) above. Of course, this analysis is quarterly rather than daily, and other important factors may also have to be controlled for when conducting an appropriate compensation analysis such as tenure as a trader and the percentage of trades in swaps, cash and futures, among others. Additionally, empirical analyses addressing the timing of transactions between allegedly tainted pairs and the reception of gifts would possibly also be undertaken.

Additional analysis related to allegations of a conspiracy would also 
have to be presented. Screens could be applied to identify clusters of brokers that seem to differentiate themselves from all other brokers with respect to characteristics relevant for the alleged conspiracy. ${ }^{196}$

2. Possible Empirical Analyses for a Hypothetical Case Brought Under Rule 180.2

In allegations of actual manipulation, we may expect the CFTC to continue following the four tests addressing the following questions: (1) did the accused have the ability to influence market prices; (2) was there an intent to create or affect prices not reflecting legitimate forces of supply and demand; (3) did artificial prices exist; and (4) did the accused cause such artificial prices.

An economic expert on an alleged manipulation case will often start by considering two main lines of inquiry. First, she will assess whether the defendant had the capability of affecting prices, and secondly, whether an artificial price was generated as a consequence of the alleged conduct. Depending on the specifics of the case, the incentive test may come in sooner or later in the analysis by the economic expert.

As an example, let's suppose the following allegations of direct and indirect manipulation of NYMEX settlement prices. The CFTC alleges that a particular individual, "the defendant," has manipulated downwards the NYMEX settlement prices for commodity $A$ on specific days during the period of 2002 through the end of 2004, and as a consequence it indirectly manipulated downwards the NYMEX settlement prices for closely related commodity $B$. Allegedly, the defendant was selling large quantities of this commodity on or about the last minute of floor trading, offering to sell at prices noticeably lower than those seen in the market at that moment in time. Allegedly, the defendant entered the market in days specifically relevant for his trading in other commodities. Namely, the defendant had a large amount of contracts for commodity $B$, which is closely related to commodity $A$. In particular, the defendant had entered into contracts to purchase large volumes of commodity $B$, whose price has a high and positive correlation with the price of commodity $A$. According to the CFTC, since the defendant's positions were significantly larger in the market for commodity $B$ than in the market for commodity $A$, what the defendant lost in terms of selling $A$ at "too low prices" he more than offset

196. For an explanation of a variety of screens that can be used when studying alleged conspiracies, see Abrantes-Metz \& Bajari, Screens for Conspiracies, supra note 176; Abrantes-Metz \& Bajari, Screens for Conspiracies Extended, supra note 176; A.B.A., Proof of CONSPIRACY under ANTITRUST Federal Laws, ch. VIII (2010). in profit by buying $B$ at "too low prices."

We will start by focusing first on the question of whether the defendant had the capability to affect market prices. The economist must first define the relevant market. Should the relevant market be essentially restricted to commodities $A$ and $B$ transacted on the floor of the NYMEX, or should it also incorporate electronic transactions on these commodities? Should transactions on these commodities performed at the London Metal Exchange (LME) be included? Should other closely related commodities also be included in the relevant market?

Secondly, the economist must determine how large are the trades placed by the defendant compared to the overall market volume to establish whether the defendant had the capability to manipulate prices. Determinations will have to be made as to the relevant time period of trading and on the location and type of trading as well. In our case, the allegations are that the defendant manipulated NYMEX settlement prices for commodities $A$ and $B$ by trading large quantities in the floor in the las few minutes of floor trading. Clearly, the economist needs to focus on the NYMEX settlement prices and on the volume during the last few minutes of trading, though the overall daily volume may also be relevant Additionally, both floor and electronic trading during the last minutes of floor trading are part of the calculations of the NYMEX settlement prices for both commodities; therefore both of these should be taken into accoun when estimating the defendant's relative market size. Often, individual floor trade volumes are not publicly available, but sometimes it is possible for the economist to provide an estimate of these in order to infer the relative size of each trade.

Once the above determinations are made, the economist will then be able to start analyzing whether prices on those markets were artificial during the days in which manipulation allegedly occurred, and in case such price artificiality is found, whether the defendant's actions were the cause. Let's suppose that in this hypothetical the relevant market is defined by the two commodities, and the transactions involved are those placed on the floor of the NYMEX and electronically. Some of the approaches that may be relevant in this context are described below.

One natural approach is to use a market model to "screen" the markets for price artificiality. The question is, "had the CFTC built such a screen to flag unexpected patterns in these NYMEX settlement prices, would it have flagged the days in which the defendant sold commodity $A$ as days in which the NYMEX settlement price was unexpectedly low?"

Let's focus on commodity $A$, as the analysis for commodity $B$ is similar in nature. The economist may construct a market model that explains variation in the daily changes in NYMEX settlement prices for 
commodity $A$ based on various exogenous variables that are not affected by the defendant's trading in this market. A market model incorporates returns (or changes) in an overall market index to track the performance of the entire economy, a commodity-specific index such as a spot index, and perhaps other factors such as ETFs. These models typically have a high explanatory power for changes in the dependent variable, NYMEX settlement prices changes in this case.

The next step is to analyze the excess returns for the NYMEX settlement prices, i.e., the part of the change in the NYMEX settlement prices which cannot be explained by legitimate changes in the variables used in the model, and to correlate these with the defendant's trading activity. Is there a statistically significant correlation between negative and statistically significant excess returns for the NYMEX settlement prices for commodity $A$ and the days that the defendant was in the market selling these futures contracts at allegedly "too low" prices?

Now, an absence of correlation may be compelling evidence of an absence of causation. But the reverse is far more tenuous: there can be a number of reasons why two things may be correlated without assuming that one causes the other. One of the most likely is that we have omitted a relevant factor from our market model that drives both the NYMEX settlement price and the defendant's decision to sell that commodity on the same day, generating a positive correlation between the two. Such a factor could be a particular piece of news on that commodity on that day, or simply the fact that the market volume has attained a high or a low, or even news related to monetary policy, for example. Hence, causality needs to be appropriately addressed in the context of an event study, in which relevant news are researched and timed to changes in relevant prices so that the cause of the price change can be identified, and intraday analyses may well be required.

Another possible analysis based on the screening model is to look into the transitions from selling and not selling the commodity. Divide the space of actions into in-in, in-out, out-out, out-in: (i) "in-in" are days in which the defendant was in the market selling the commodity and continued in the market the following day; (ii) "out-in" represent moving from a day in which he did not sell the commodity to a day in which he did, and comparable definitions for out-out and in-out. The economic expert may test whether there are sudden price jumps downwards on out-in days, and sudden price jumps upwards on in-out days, which would be consistent with the allegations of manipulation downwards of commodity $A$. A variety of other tests could also be performed in this framework.

Other, more common tests of price artificiality include the analysis of the basis for the relevant contracts, defined as the difference between the futures price today for the relevant contract minus the spot or cash price today for the same commodity. Comparisons can be made between the basis during days in which the defendant sold commodity $A$ against those days in which he did not, or between prior and post alleged manipulation periods, or against the basis of other untainted contracts. Is the basis for the allegedly manipulated contracts negative (i.e., does backwardation exist), or more negative on days in which the defendant sold futures contracts for commodity $A$ at allegedly "too low" prices? Movements in the basis may also have to be controlled for in terms of other relevant market variables.

Yet another set of analyses that an economist will need to undertake are those related to the intent to manipulate, as discussed in section 2. Despite the difficulty in analyzing intent, an economic expert may have several potentially relevant analyses to pursue.

Analyses related to liquidity, market depth and price discovery, described above in the context of price artificiality, may all also play an important role when addressing intent. If the defendant intends to affect prices, it is easier to do so when trading during times of the day in which liquidity is low, which corresponds to times when the market does not have much depth, or on particular days in which that is more the case than others. Additionally, he may more easily affect prices if he tries to affect the market in which price discovery takes place.

Analyses of trading patterns may be critical when addressing intent. They do not require a price effect, but simply flag trading patterns consistent with a higher likelihood of intent to affect prices as being "unusual" in some sense for these markets. One such approach is to empirically study the reasons why the defendant decided to trade in the specified markets on the particular days that he did, using factors that can be measured. Was his decision to trade based on relevant exogenous events? Does he typically trade on days in which volume is high, or days in which particular macroeconomic news occur? Decision-making models may be developed and estimated to determine the factors more highly correlated with the defendant's trading patterns to see if these, rather than an intent to affect price, can explain his trading pattern.

An economic expert will likely also want to study profitability from the alleged conduct. She will compute actual profitability from this strategy and compare it against defendant's profitability in other moments in time. She may also study whether the alleged misconduct is timed to the defendant's quarterly assessments on which his compensation will be determined. Additionally, she may estimate shadow strategies that the defendant would likely have undertaken had he not traded in the commodities markets allegedly manipulated, to estimate what would but- 
for profits have been under such shadow trading patterns and compare them against his actual profits.

The lower CFTC burden of proof enables more elaborate, more indepth, and more creative economic and empirical approaches. With proportionally less emphasis on the subjective state of intent, the new recklessness standard denotes greater willingness to consider objective indicia of manipulation. Although the law has always made use of empirical proofs in manipulation, it has done so grudgingly at times. The new rules create new reasons and opportunities for the law to make use of economic expertise.

\section{Screens at the Pleading Stage ${ }^{197}$}

Many argued that our pre-existing manipulation laws were sufficient to address the challenges manipulation poses. For example, Pirrong implied that the faults in Commodity Exchange Act enforcement came largely from the unwillingness of the courts and agencies to engage in statistical analysis of prices - but that the law itself was sufficient. ${ }^{198}$ One student note examining Libor recommended cosmetic changes to the BBA's Libor governance, but saw no need for legal recommendations, ${ }^{199}$ and another note surveyed manipulation scholarship in the wake of the Sumitomo copper manipulation and argued that existing laws should suffice. ${ }^{200}$ For those who were content with the status quo, Dodd-Frank has created open season for manipulation enforcement and given regulators too much power.

While the new rules extend their reach to cover transactions that would have eluded enforcement before, there are also concerns about the power of the dramatic expansion of regulatory authority under Dodd-Frank. Just as the Rules will require economic methods to operate, their dizzying scope should be limited by broad application of these methods at the pleading stage. With new recklessness and attempt prongs, many more defendants can be drawn into investigation and litigation. The defensive use of econometric tools will prove vital for innocent defendants who seek to avoid suit. Ideally, the courts will be receptive to such approaches,

97. This section extends analysis in Rosa Abrantes-Metz, Design and Implementation of Screens and Their Use by Defendants, COMPETITION POL'Y INT'L ANTITRUST C Sept. 2, 2011

198. Pirrong, supra note 50

199. Justin T. Wong, Libor Left in Limbo; A Call for More Reform, 13 N.C. BANKING INST. 365 (2009).

200. Benjamin E. Kozinn, The Great Copper Caper: Is Market Manipulation Really a Problem in the Wake of the Sumitomo Debacle?, 69 Fordham L. Rev. 243 (2000). allowing economic proof at the pleading stages as defendants advert to Iqbal and Twombly. As discussed in Abrantes-Metz (2010), some of these patterns may indeed be sufficiently unusual as to pass the higher standards for pleading antitrust conspiracy claims set forth by the Supreme Court decision in Bell Atlantic Corp. v. Twombly. ${ }^{201}$ This section urges that the failure to trigger any screen may be useful to a court in determining whether a plaintiff has pled with sufficient specificity to overcome Twombly.

If by contrast, courts allow their unfettered use by the Commission and plaintiffs, the new rules could see substantial costs and risks for legitimate market participants and lower the quality and liquidity of price discovery and hedging. Concerns were voiced by a number of market participants and experts in comments submitted during the rule-making period for sections 180.1-180.2, expressing worries about the proposed rules. The American Bar Association emphasized that the addition of the OTC swap market to the scope of the manipulation rules makes it all the more important that rules be clear. Unlike market-based participants, OTC participants do not yet have real-time feedback from the Commission or exchange as to the legality of their activities. ${ }^{202}$

Platts's comment, for instance, focused on its role providing price discovery and the ways in which the proposed rules against price manipulation could potentially create a disincentive to the entities that provide Platts with information, hindering its data gathering activities. Argus's comment was straightforwardly critical. Argus is a major provider of price information on various physical commodities. Its concern was that "the proposed rules may unnecessarily chill the voluntary submission of transaction related data by market participants to compilers of price indices." 203 As Platts put it, "[e]ffective price discovery in physical energy markets depends on the willingness of companies to recognize the collective good of engaging in price formation through the voluntary and transparent reporting of trade data, including bids, offers and actual transactions, to publishers of price assessments such as Platts."204 Platts also indicated that the good faith exception for false reporting that exist

201. 550 U.S. 554,555 (2007)

202. A.B.A. Derivatives Section Comment Letter on Rules 180.1 and 180.2 at 4 ; William P. Albrecht, Regulation of Exchange-Traded and OTC Derivatives: The Need for a Comparative Institution Approach, 21 J. CORP. L. 111, 112 (1995) ("United States futures Comp derivatives."); exchanges arc Roberta Romano, A Thum (discussing regulation of swaps).

MD. L. REV. 1,55 (1996) (discussing regulation of swaps).
203. Argus comment on Rules 180.1 and 180.2 , at 1 .

203. Argus comment on Rules 180.1 and 180.2 , at 1 .
204. Platts Comment Letter on Rules 180.1 and 180.2 , at 1 . 
under Dodd Frank had a long and successful provenance, dating back to the Federal Energy Regulatory Commission's 2003 Policy Statement on Natural Gas and Electric Price Indices, and successfully argued for its similar application here. ${ }^{205}$

Though the outer reaches of the new rule's power is extensive, its true reach will depend on judicial treatment. In particular, courts may be inclined to moderate its power at the pleading stage. If legitimate market participants can dispense with the cost of litigating CEA claims before those expenses mount, than much of the uncertainty and cost will be relieved. ${ }^{206}$

We describe below the process of developing a new screen for the purpose of evaluating a purported manipulation. Innovative screens like this one can help particularly at the pleading stage. If the plaintiff's manipulation claim can be cheaply and efficiently discredited, then more resources can be dedicated to meritorious claims and innocent defendants can avoid serious costs. The use of these tools will be more important than ever in establishing limits to the power of the new rules.

Innovations in screens, typically driven by litigation parties, can, if credited in court, constitute genuine improvements in how and what legal factfinders can know. Party innovations can also drive the creation of tools that are subsequently added to the arsenal of tools for prosecuting financial manipulation by regulators. Given their tremendous complexity, commodity manipulation will often require the development of new screens specifically tailored to the allegations at hand. Below we provide a closing descriptive summary of the many uses that can be made of screens.

\section{Uses of Screen.}

A screen is a statistical test aimed at identifying potential market misconduct. Its uses are many, but non-litigation detection and litigation are the primary families of uses.

\section{Detection}

Perhaps the primary use that is made of screens is detection. ${ }^{20}$

205. Platts Comment Letter on Rules 180.1 and 180.2 at 2 .

206. One important factor to note in adjudicating between the promise and overbreadth of the new CFTC rules is the argument of Keith Hylton that pleading standards should depend on the evidentiary demands and social costs of a given form of litigation. See Keith N. Hylton, When Should a Case Be Dismissed? The Economics of Pleading and Summary N. Hylton, When Should a Case Be Dismissed? The Econt
Judgment Standards, 16 Sup. CT. Econ. Rev. 39 (2008).

207. Below we provide examples using just one kind of screen that one of the co-
Detection involves employing a screen to identify a potential manipulation, as was discussed in depth above. Detection is of use to multiple individuals impacted or interested in potential market manipulations. Competition authorities and government regulators will want to make extensive use of screens to ease the work of identifying potential extensive use of scring regulatory scrutiny. Academics interested in the mo want to 年 corroborate their case. ${ }^{20}$ Further afield are additional uses for screens. Companies considering prospective joint ventures or mergers an acquisitions stand to benefit from identifying potential liabilities. Self-

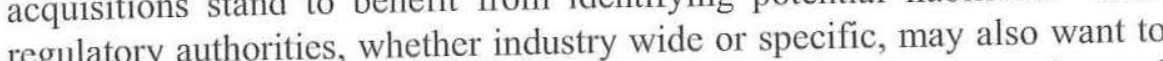
Lastly, corporate internal compliance stands to benefit enormously from well-applied screens, which may nip forthcoming manipulations in the bud.

\section{Litigation}

The other primary forum for the effective and efficient use of screens is in litigation. ${ }^{209}$ Every constituent of the litigation process will benefit from the apt use of screens. Screens are often used, as discussed above, for identifying potential manipulation and can be aggressively utilized at the identifying potential manipulation and can be agress to

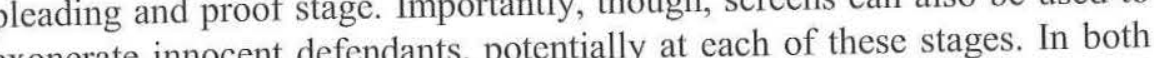
exonerate innocent defom appropriate use of cases, it is the factfinder that statistical evidence. Moreover, this is true at unexpected phases of an action. Class certification and damages will also potentially benefit from screen application. ${ }^{210}$

\section{CONCLUSION}

The law of commodities manipulation has been definitionally

athors has also successfully employed. See, e.g., Cindy Durtschi, William Hillison \& Carl authors has also successfully employed. See, e.g., Cind Detecting Fraud in Accounting Data, Pacini, The Effective Use of Benford s Law to Assist in Delect's Law, 26:3 AM. STaTiSTician 5 J. ForENSIC ACCOUNTING 17 (2004); Hal Varian, Benford's Law, 26.3 AM. STATSTICIAN 65 (1972); Stephen Battersby, Statistics Hint at Fraud in Iranian Election, NEW ScIENTIST, June 24,2009 , at 10 .

208. Abrantes-Metz, Screens for Conspiracies and their Multiple Applications, supra note 176; Rosa Abrantes-Metz et al, Is the Market Being Fooled? An Error-Based Screen for Manipulation (2007) (unpublished manuscript), available at http://papers.ssrn.com/so for

列 209. Rosa Abrantes-Me PoLicy INT. J. (forthcoming 2012)

Compliance, COMPETITION POLICY INT. J.
210. Abrantes-Metz, supra note 176. 
confused, doctrinally challenged, and nearly unwinnable in practice. In the aftermath of a disastrous global financial crisis, the CFTC has adopted a new set of regulations of striking scope and depth. This Article analyzed the tectonic shift those regulations represented for the legal landscape and made three primary claims. First, manipulation in financial markets increasingly requires powerful tools for detection and prosecution. The inclusion of swaps within the CEA manipulation regime, and the worldwide focus on Libor, underscores that the new CFTC rules have dramatic advantages alongside their significant potential for abuse. Second, that the new CFTC rules require more complex, subtle, and innovative economic analyses. While engaging the debate at a theoretical level, we also provided extensive demonstrations of how a sophisticated economic approach might work under the new law. Third, we argued for an increased role for empiricism in the evidentiary law surrounding manipulation, re-engaging a decades-old debate on the place of economic analyses in the law. 